\title{
Increasing the length of poly-pyrimidine bulges broadens RNA conformational ensembles with minimal impact on stacking energetics
}

\author{
DAWN K. MERRIMAN,${ }^{1}$ JIAYI YUAN,${ }^{1,2}$ HONGLUE SHI, ${ }^{1}$ ANANYA MAJUMDAR ${ }^{3}$ DANIEL HERSCHLAG, ${ }^{4}$ \\ and HASHIM M. AL-HASHIMI ${ }^{1,5}$ \\ ${ }^{1}$ Department of Chemistry, Duke University, Durham, North Carolina 27708, USA \\ ${ }^{2}$ Department of Biology, Duke University, Durham, North Carolina 27708, USA \\ ${ }^{3}$ Biomolecular NMR Facility, Johns Hopkins University, Baltimore, Maryland 21218, USA \\ ${ }^{4}$ Department of Biochemistry, Stanford University, Stanford, California 94305, USA \\ ${ }^{5}$ Department of Biochemistry, Duke University Medical Center, Durham, North Carolina 27710, USA
}

\begin{abstract}
Helical elements separated by bulges frequently undergo transitions between unstacked and coaxially stacked conformations during the folding and function of noncoding RNAs. Here, we examine the dynamic properties of polypyrimidine bulges of varying length $(n=1-4,7)$ across a range of $\mathrm{Mg}^{2+}$ concentrations using HIV-1 TAR RNA as a model system and solution NMR spectroscopy. In the absence of $\mathrm{Mg}^{2+}$, helices linked by bulges with $n \geq 3$ residues adopt predominantly unstacked conformations (stacked population $<15 \%$ ), whereas one-bulge and two-bulge motifs adopt predominantly stacked conformations (stacked population $>74 \%$ ). In the presence of $3 \mathrm{mM} \mathrm{Mg}^{2+}$, the helices predominantly coaxially stack (stacked population $>84 \%$ ), regardless of bulge length, and the midpoint for the $\mathrm{Mg}^{2+}$. dependent stacking transition is within threefold regardless of bulge length. In the absence of $\mathrm{Mg}^{2+}$, the difference between free energy of interhelical coaxial stacking across the bulge variants is estimated to be $\sim 2.9 \mathrm{kcal} / \mathrm{mol}$, based on an NMR chemical shift mapping with stacking being more energetically disfavored for the longer bulges. This difference decreases to $\sim 0.4 \mathrm{kcal} / \mathrm{mol}$ in the presence of $\mathrm{Mg}^{2+}$. NMR RDCs and resonance intensity data show increased dynamics in the stacked state with increasing bulge length in the presence of $\mathrm{Mg}^{2+}$. We propose that $\mathrm{Mg}^{2+}$ helps to neutralize the growing electrostatic repulsion in the stacked state with increasing bulge length thereby increasing the number of coaxial conformations that are sampled. Energetically compensated interhelical stacking dynamics may help to maximize the conformational adaptability of RNA and allow a wide range of conformations to be optimally stabilized by proteins and ligands.
\end{abstract}

Keywords: NMR; RNA folding; HJH motifs; RNA dynamics; RNA bulges; HIV

\section{INTRODUCTION}

Studies over the past two decades have established a plethora of functions for noncoding RNAs (ncRNAs) (Eddy 2001; Gesteland et al. 2006; Wahl et al. 2009; Cech and Steitz 2014). The biological mechanisms of many ncRNAs require highly coordinated conformational changes that are not only essential for the proper folding and assembly of RNA and ribonucleoprotein (RNP) complexes but also provide the basis for RNA-based molecular machines and switches (Cruz and Westhof 2009; Dethoff et al. 2012; Mustoe et al. 2014b). A common RNA conformational transition involves changing the orientation of heli-

Corresponding author: hashim.al.hashimi@duke.edu

Article is online at http://www.rnajournal.org/cgi/doi/10.1261/rna. 066258.118. cal domains linked by bulges, internal loops, and higher order junctions from linear coaxially stacked conformations to what can be a broad range of bent interhelical conformations. Such transitions can help orient motifs involved in tertiary contacts (Kim et al. 1974; Robertus et al. 1974; Jack et al. 1976; Murphy et al. 1994) or optimize intermolecular interactions with ligands (Duchardt-Ferner et al. 2010; Stelzer et al. 2010), proteins (Leulliot and Varani 2001; Noller 2005), and metal ions (Bassi et al. 1995; Ippolito and Steitz 1998) that bind interhelical junctions.

\footnotetext{
(C) 2018 Merriman et al. This article is distributed exclusively by the RNA Society for the first 12 months after the full-issue publication date (see http://rnajournal.cshlp.org/site/misc/terms.xhtml). After 12 months, it is available under a Creative Commons License (Attribution-NonCommercial 4.0 International), as described at http://creativecommons.org/licenses/by-nc/4.0/.
} 
Indeed, a survey of the Protein Data Bank (PDB) (Berman et al. 2000) shows that RNA helices linked by bulges tend to predominantly adopt near coaxially stacked conformations whereas kinked conformations are more often observed in RNA-protein and RNA-ligand complexes, particularly for longer bulges (Fig. 1A). A deep understanding regarding the dynamic behavior of helices across junctions is key for advancing RNA structure prediction (Somarowthu 2016; Miao and Westhof 2017), RNA-targeted drug discovery (Stelzer et al. 2011; Hermann 2016), the design of RNA-based devices (Aragiannis et al. 2016; Ohno and Saito 2016) as well as for understanding and manipulating biological RNA and RNA/protein machines.

The most common RNA interhelical junction is the bulge motif, a single asymmetric strand that adjoins two helical domains (Fig. 1B; Ignacio Tinoco et al. 1989; Turner 1992; Hermann and Patel 2000). Studies using transient electric birefringence (TEB) have shown that at low salt concentrations ( $2 \mathrm{mM} \mathrm{NaCl})$, poly $(\mathrm{A})$ and poly(U) bulges induce kinks that increase as the bulge length increases from 1 to 6 nucleotides (nts) (Zacharias and Hagerman 1995a). Additional studies using Föster resonance energy transfer (FRET) show that in $100 \mathrm{mM} \mathrm{NaCl}$ the average bend angle
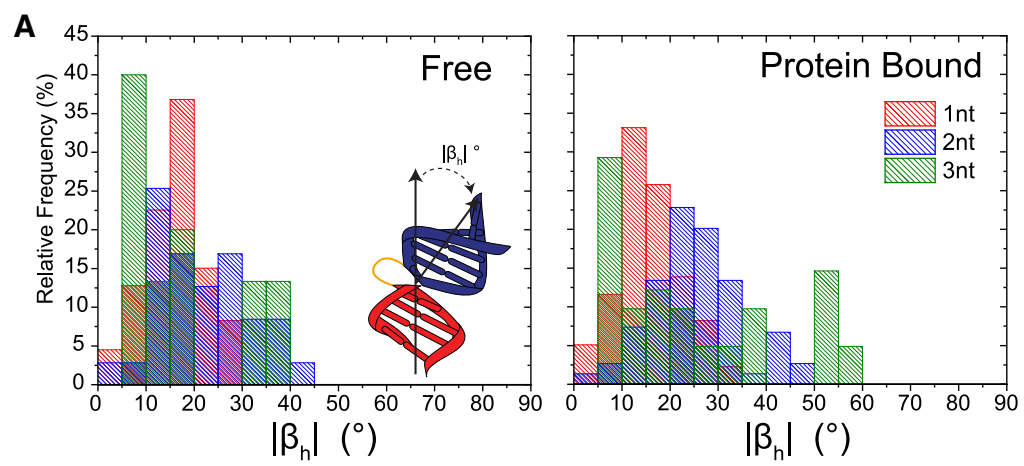

B

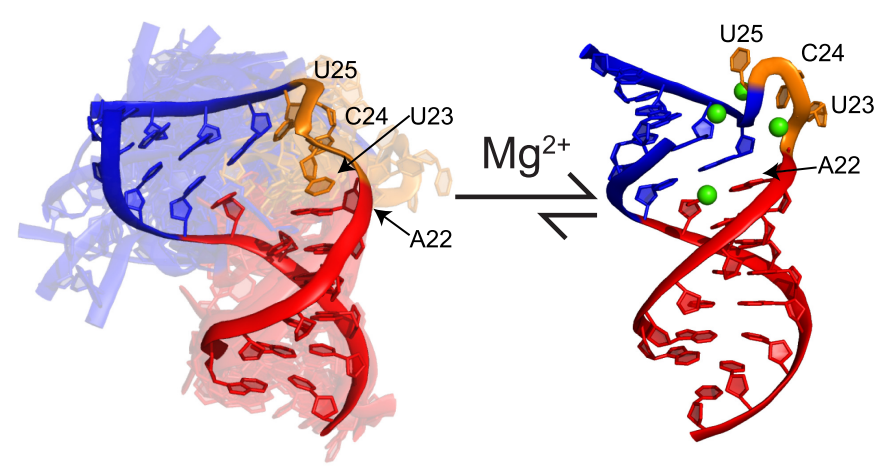

FIGURE 1. Changes in the interhelical orientation across RNA bulges. (A) The interhelical bend angles across 1 (red), 2 (blue), and 3 (green) nt bulges based on a survey of RNA structures in the PDB (see Materials and Methods). Results are shown for free RNA structures (left) and bound to proteins and ligands (right). (B) Previously proposed (Casiano-Negroni et al. 2007) two-state equilibrium in HIV-1 TAR between (left) an unstacked flexible ensemble (Salmon et al. 2013) and (right) stacked rigid conformation stabilized by divalent cations. The stacked structure shown is the X-ray structure of TAR (PDBID: 397D) (Ippolito and Steitz 1998) determined in $100 \mathrm{mM} \mathrm{Ca}^{2+}$ (highlighted as green spheres). between RNA helices increases up to 7 nts, but that further addition of bulge nucleotides results in more linear conformations, likely because the bulge nucleotides can pair up to form helical stems that impose unique topological constraints (Gohlke et al. 1994). This increase in average kink angle with bulge length can be explained by simple topological models in which helices sample broader interhelical distributions as connectivity constraints are weakened (Chu et al. 2009; Mustoe et al. 2014a). For $U_{n}$ bulges (where $\mathrm{n}$ is equal to the number of bulge nucleotides), addition of divalent metal ions, such as $\mathrm{Mg}^{2+}$ or $\mathrm{Ca}^{2+}$, helps to neutralize electrostatic charge repulsion and promote interhelical coaxial stacking through a process that likely requires the flipping out of the bulge nucleotides (Zacharias and Hagerman 1995a; Ippolito and Steitz 1998; Casiano-Negroni et al. 2007). However, for $A_{n}$ bulges, a greater tendency to stack intrahelically hinders interhelical coaxial stacking even in the presence of $\mathrm{Mg}^{2+}$ (Kalnik et al. 1990; Zacharias and Hagerman 1995a). Together, these studies show that many competing factors, including the length and sequence of the bulge as well as the concentration and identity of metal ions present in solution, can influence the dynamic behavior of bulges (Bhattacharyya and Lilley 1989; Hsieh and Griffith 1989; Bhattacharyya et al. 1990; Tang and Draper 1990; Riordan et al. 1992; Gohlke et al. 1994; Zacharias and Hagerman 1995a).

The trinucleotide (UCU) bulge in the transactivation response element (TAR) RNA from the human immunodeficiency type-1 virus (HIV-1) has served as a model system for studying the behavior of poly-pyrimidine bulges (Fig. 1B; Riordan et al. 1992; Hermann and Westhof 2000; Pitt et al. 2004; Casiano-Negroni et al. 2007; Dethoff et al. 2008; Do et al. 2012; Jalalirad et al. 2012; Shi et al. 2017). Stacking of helices across the TAR bulge is proposed to play important roles in the assembly of a RNP complex that activates transcription (Roy et al. 1990; Calnan et al. 1991). In addition, the TAR helices sample a variety of unstacked conformations (Faber et al. 2000; Davis et al. 2004; Murchie et al. 2004; Zhang et al. 2006; Frank et al. 2009; Stelzer et al. 2010; Shi et al. 2017), which can be stabilized when bound to different small molecules (Jones and Peterlin 1994; Hermann 2016).

Biophysical studies using a variety of techniques (Zacharias and Hagerman 
1995b; Ippolito and Steitz 1998; Zhang et al. 2003, 2006; Casiano-Negroni et al. 2007; Stelzer et al. 2010; Lu et al. 2011; Salmon et al. 2013; Dickson et al. 2014; Mustoe et al. 2014a; Shi et al. 2017) have shown that at low salt concentrations ( $25 \mathrm{mM} \mathrm{NaCl}$ ) and in the absence of divalent cations, the two TAR helices are unstacked and on average kinked by $\sim 45^{\circ}$ relative to one another, forming a highly dynamic ensemble of interhelical conformations (Zacharias and Hagerman 1995b; Aboul-ela et al. 1996; Al-Hashimi et al. 2002; Dethoff et al. 2008). The bulge residue $\mathrm{U} 23$ stacks on the junctional A22, while bulge residues C24 and U25 are looped out and highly flexible (Fig. 1B, left). The stacked state is thought to be disfavored in low concentrations of monovalent metal ions and in the absence of divalent metal ions due to electrostatic repulsion at the bulge (Casiano-Negroni et al. 2007). In contrast, in the presence of divalent cations $\left(\mathrm{Mg}^{2+}\right.$ or $\left.\mathrm{Ca}^{2+}\right)$, the two TAR helices adopt a coaxially stacked and more rigid conformation in which all three bulge nucleotides are flipped out (Fig. 1B, right; Ippolito and Steitz 1998; Al-Hashimi et al. 2003; Casiano-Negroni et al. 2007). A crystal structure of the coaxially stacked TAR conformation (interhelical bend angle is $\sim 5^{\circ}$ ) shows four $\mathrm{Ca}^{2+}$ ions that help neutralize electrostatic repulsion through a network of innerand outer-sphere interactions (Fig. 1B, right; Ippolito and Steitz 1998). NMR studies of TAR in the presence of $\mathrm{Mg}^{2+}$ (Al-Hashimi et al. 2003; Casiano-Negroni et al. 2007) show that it adopts a stacked conformation with flipped out bulge nucleotides similar to that observed in a high resolution $\mathrm{X}$-ray structure of TAR in the presence of $\mathrm{Ca}^{2+}$ (Ippolito and Steitz 1998), suggesting the interactions with $\mathrm{Ca}^{2+}$ are likely similar to those observed with $\mathrm{Mg}^{2+}$. NMR studies indicate also that TAR exists in a twostate dynamic equilibrium between the rigid coaxial and flexible unstacked conformations (Al-Hashimi et al. 2003; Casiano-Negroni et al. 2007). Increasing the concentration of $\mathrm{Mg}^{2+}$ or $\mathrm{Na}^{+}$(Casiano-Negroni et al. 2007), shortening the bulge from 3 to 2 nts (Merriman et al. 2016), or replacing A22-U40 with G22-C40 shifts the equilibrium in favor of the coaxial conformation (Stelzer et al. 2010).

It is interesting to note that while the sequence of HIV-1 TAR is highly conserved, TAR variants with UU bulges exist in HIV-1 isolates (HIV-1 mal and HIV-1 U455), Simian immunodeficiency virus (SIV) (Berkhout 1992), and in the twofold TAR hairpins of HIV type 2 (HIV-2) (Berkhout 1992). Cellbased assays show that while the two bulge (UU) TAR variant supports transcriptional activation, single bulge or TAR variants lacking the bulge significantly inhibit transcriptional activation (Roy et al. 1990). This effect could be due to disruption of the U23-A27-U38 base-triple which is thought to be important for Tat binding (Puglisi et al. 1992; Brodsky and Williamson 1997; Hennig and Williamson 2000) and/or because a degree of interhelical kinking across the bulge is important for transcriptional activation.
Here, we build on prior studies of HIV-1 TAR and use NMR spectroscopy to investigate how systematically varying the bulge length impacts the dynamic properties of unstacked and stacked states as well as their relative energetics. Specifically, we investigate various length uridine bulge ( $n=1,2,4$, and 7$)$ as compared to the wild-type HIV-1 TAR UCU bulge, which has been shown to behave similarly to the UUU bulge based on biophysical and functional studies (Roy et al. 1990; Sumner-Smith et al. 1991; Berkhout 1992; Riordan et al. 1992). We find that apart from the $n=1$ bulge, all $U$ bulge variants $[n=2,3(U C U)$, 4, and 7] exhibit a two-state $\mathrm{Mg}^{2+}$-dependent stacking transition. Increasing the bulge length leads to broader conformational distributions in both the stacked and unstacked ensemble but has a limited effect on the energetics of coaxial interhelical stacking in the presence of $\mathrm{Mg}^{2+}$. Energetically compensated stacking dynamics may help to maximize the conformational adaptability of RNA, allowing a wide range of conformations to be optimally stabilized by proteins and ligands, and sampled during folding of large RNAs.

\section{RESULTS}

\section{$\mathrm{Mg}^{2+}$-dependent interhelical stacking transition monitored by NMR chemical shift mapping}

We used NMR chemical shift mapping experiments to examine whether four poly $(U)$ variants of wtTAR containing one, two, four, and seven uridine bulges $\left(U_{n} T A R\right.$, where $n$ denotes the number of uridines in the bulge motifs, Fig. 2A) also undergo $\mathrm{Mg}^{2+}$-dependent interhelical stacking transitions. Prior studies showed that coaxial stacking of wtTAR induced by increasing the concentration of either $\mathrm{Mg}^{2+}$ or $\mathrm{Na}^{+}$(Al-Hashimi et al. 2003; Casiano-Negroni et al. 2007) or through replacement of A22-U40 with G22-C40 (Stelzer et al. 2010) results in specific chemical shift perturbations (CSPs) at nucleotides in and around the bulge, specifically residues A22, U23, and C24 (Fig. 2A). These CSPs report on conformational differences between the unstacked and stacked states with U23 being partially flipped in in the unstacked state but flipped out in the stacked conformation (Fig. 1B).

In prior studies of wtTAR (UCU-TAR), 2D HSOC spectra were collected following incremental addition of $\mathrm{Mg}^{2+}$ (Casiano-Negroni et al. 2007). Here, we carried out analogous experiments by dialyzing each TAR NMR samples into the desired $\mathrm{Mg}^{2+}$ concentration. This equilibration was important to properly account for the free $\left[\mathrm{Mg}^{2+}\right]$ when deriving thermodynamic parameters of interest. We also used lower RNA concentrations $(25 \mu \mathrm{M})$ to facilitate comparison to other biophysical studies that use lower RNA concentrations and in which the free concentration of $\mathrm{Mg}^{2+}$ is assumed to be known. For each TAR variant, NMR spectra were recorded at eleven different $\mathrm{Mg}^{2+}$ 
A

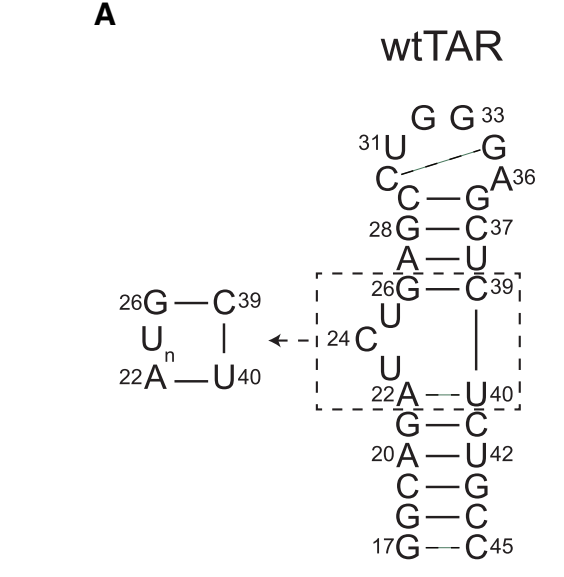

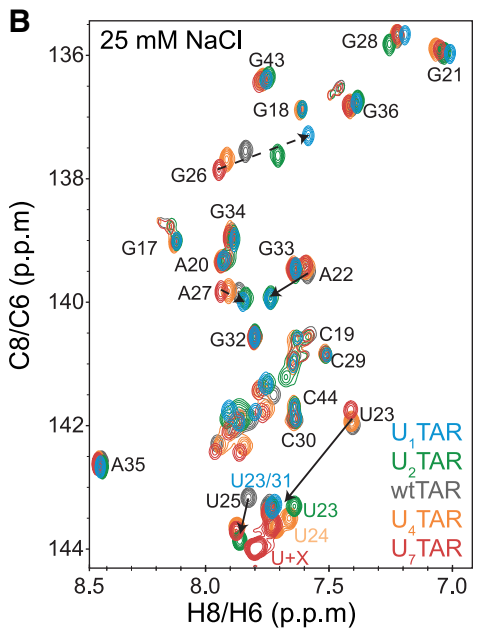
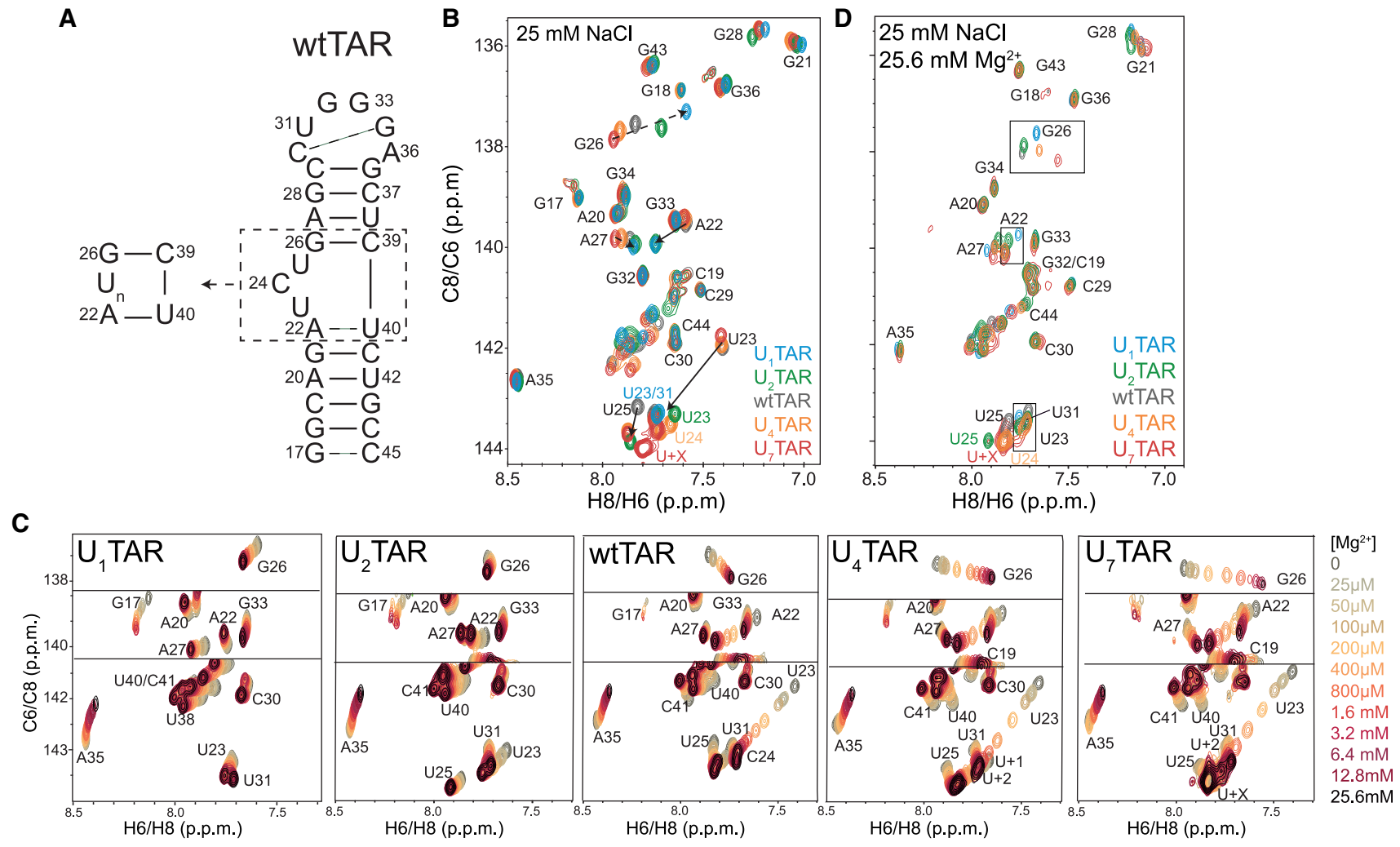

FIGURE 2. NMR chemical shift mapping of bulge variants. (A) The secondary structure of HIV-1 TAR, mutations of the TAR variants, in which the UCU bulge is replaced with poly-pyrimidine bulges of varying length. (B) Aromatic 2D HSQC overlay of wtTAR and TAR bulge variants, with arrows pointing from the largest $\left(U_{7} T A R\right)$ to the smallest $\left(U_{1} T A R\right)$ bulge variant. Solid and dashed lines highlight CSPs which are similar or different to CSPs observed for wtTAR with $\mathrm{Mg}^{2+}$, respectively (Casiano-Negroni et al. 2007). (C) Overlays of aromatic SOFAST-HMQC spectra for the TAR variants recorded at various magnesium concentrations, highlighting residues A22 and U23 that report on stacking as well as the more complex behavior observed at residue G26. (D) Aromatic SOFAST-HMQC overlay of wtTAR and bulge mutants in $25.6 \mathrm{mM} \mathrm{Mg}^{2+}$. CSPs with relatively large differences between bulge variants, as compared to helical resonance, suggest the ensemble of the stacked state varies between bulge variants; they are highlighted in black boxes.

concentrations at $25^{\circ} \mathrm{C}$ using aromatic SOFAST-HMOCs (Sathyamoorthy et al. 2014) for optimal data collection.

In the absence of $\mathrm{Mg}^{2+}$, shortening or elongating the wtTAR bulge resulted in large CSPs at the same residues in and around the bulge that experience CSPs in wtTAR upon coaxial interhelical stacking (Fig. 2B; Supplemental Fig. 1A). Relative to wtTAR, shortening the bulge resulted in CSPs that are similar to those observed upon addition of $\mathrm{Mg}^{2+}$ or $\mathrm{Na}^{+}$, whereas elongating the bulge leads to oppositely shifted CSPs (Fig. 2B; Supplemental Fig. 1B), similar to the low-salt form of wtTAR. Additionally, normalized resonance intensity analysis reveals that the local bulge dynamics at picosecond-to-nanosecond timescales increases as the bulge is elongated (Supplemental Fig. 2A). These results indicate that shortening/elongating the bulge leads to an increase/decrease in the fractional population of the stacked state.

Increasing the concentration of $\mathrm{Mg}^{2+}$ resulted in CSPs for all TAR variants, with the largest CSPs generally observed in and around the bulge as reported previously for wtTAR (Fig. 2C; Supplemental Fig. 1D). The directions of the CSPs in the TAR variants were also similar to those observed for wtTAR and are consistent with an increase in the fractional population of the stacked state. $U_{1}$ TAR experiences smaller CPSs and does not reach the chemical shift positions observed for the other variants, indicating that it does not undergo an $\mathrm{Mg}^{2+}$-dependent stacking transition. The NMR spectra of the TAR variants recorded at low salt differ significantly (Fig. 2B), reflecting differences in the relative populations of stacked and unstacked states as well as potential differences in the stacked and unstacked ensemble. Conversely, the spectra recorded at saturating $\mathrm{Mg}^{2+}$ concentration are much more similar, consistent with stabilization of more similar coaxially stacked conformations (Fig. 2D; Supplemental Fig. 1C).

\section{Similar midpoints for the $\mathrm{Mg}^{2+}$-dependent stacking transition}

With a few exceptions noted below, all $\mathrm{Mg}^{2+}$-dependent CSPs measured for the TAR variants could be satisfactorily 
fit to a two-state model, suggesting that all TAR variants exist in a dynamic equilibrium between unstacked and stacked conformations (Fig. 3A; Supplemental Fig. 3; Supplemental Table 1). We analyzed the fitted $\mathrm{Mg}_{1 / 2}$ values representing the midpoint for the $\mathrm{Mg}^{2+}$-dependent conformational transition. Because the stacked conformation is significantly populated for many of the variants in $25 \mathrm{mM} \mathrm{NaCl}$ even in the absence of $\mathrm{Mg}^{2+}$, the midpoints do not necessarily represent the concentration at which stacked and unstacked populations are $50 \%$. Rather, the $\mathrm{Mg}_{1 / 2}$ values report on the energetics of $\mathrm{Mg}^{2+}$ association, which in turn depends on the energetics of coaxial stacking as well as the strength of the metal-RNA interactions.

The $\mathrm{Mg}_{1 / 2}$ values tend to be higher $(\sim 0.4 \mathrm{mM})$ for resonances within helices that are far from the bulge and that are not sensitive to the stacking transition (Fig. 3B, top). These $M g_{1 / 2}$ values vary insignificantly across the different bulge variants and likely report small local conformational changes due to interactions with ion atmosphere. In contrast, smaller $\mathrm{Mg}_{1 / 2}$ values (0.1-0.4 mM) were observed for resonances A22-C8 and U23-C6, which are sensitive to the stacking transition (Fig. 3A). These values do differ across the TAR variants, and tend to be smaller for shorter bulge variants, reflecting increased tendencies to form the stacked conformation that is stabilized by $\mathrm{Mg}^{2+}$ (Fig. 3B, bottom).

For $\mathrm{U}_{1} \mathrm{TAR}$, all of the measured $\mathrm{Mg}_{1 / 2}$ values were $\sim 0.4$ $\mathrm{mM}$, consistent with the absence of a metal-dependent
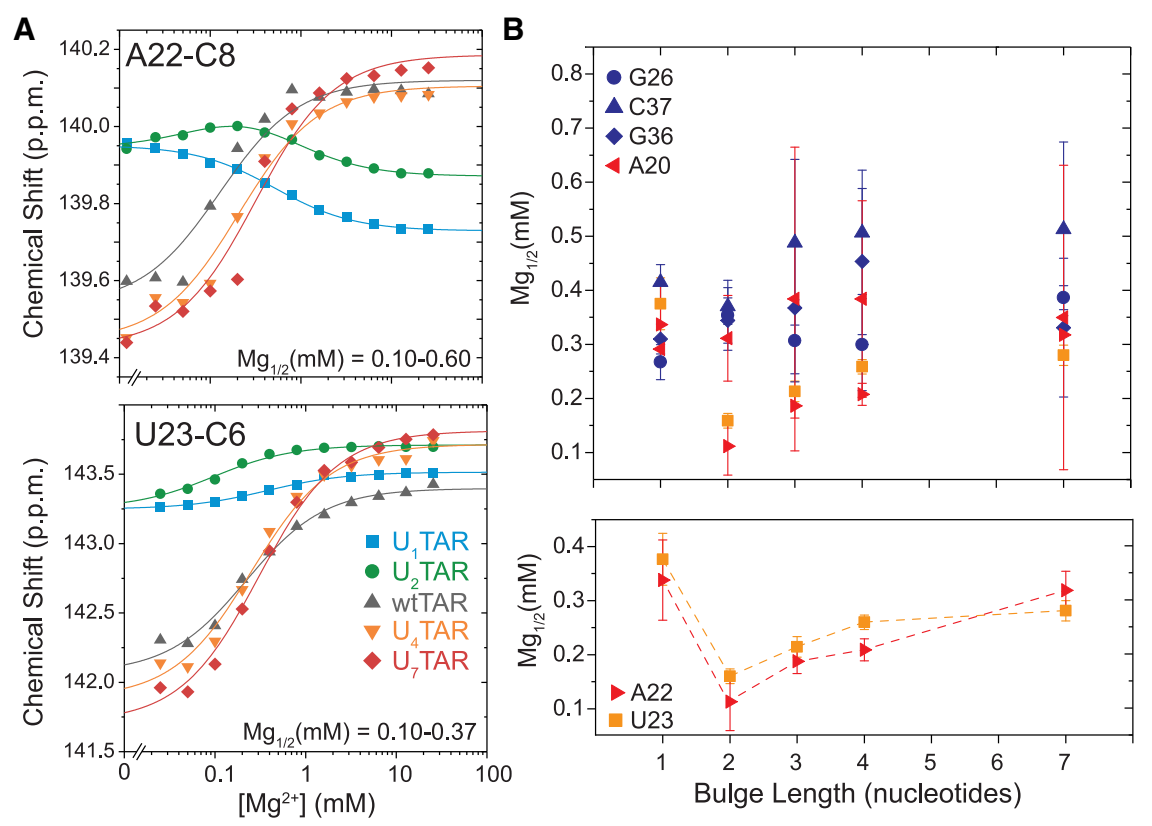

FIGURE 3. Measurement of apparent $\mathrm{Mg}_{1 / 2}$ based on NMR CSPs. (A) $\mathrm{Mg}_{1 / 2}$ fits for wtTAR and bulge variants at $\mathrm{A} 22-\mathrm{C} 8$ and $\mathrm{U} 23-\mathrm{C} 6$, which are sensitive to the stacking transition (see inset for color and symbol legend). (B) $\mathrm{Mg}_{1 / 2}$ values as a function of bulge length for all resonances in common between TAR variants in helix 1 (red), bulge (orange), and helix 2 (red) (top, see inset for symbol legend) and specific comparison of A22 and U23 (bottom). stacking transition (Fig. 3B, top). Additionally, $\mathrm{Mg}^{2+}$ midpoints for G26 and A22-C2 were $\sim 0.4 \mathrm{mM}$, consistent with the nonspecific $\mathrm{Mg}^{2+}$ binding rather than interhelical stacking. Finally, we note that the CSPs for A22-C8 in $\mathrm{U}_{2} T A R$ deviate from two-state behavior (Fig. 3A; Supplemental Fig. 4; Supplemental Table 2). Fitting to a two-site binding equation (see Materials and Methods) resulted in a low $\mathrm{Mg}_{1 / 2}$ value of $0.10 \mathrm{mM}$ consistent with $\mathrm{Mg}^{2+}$-dependent coaxial interhelical stacking and a higher $\mathrm{Mg}_{1 / 2}$ that is consistent with nonspecific interactions with the ion atmosphere (Supplemental Fig. 4; Supplemental Table 2).

\section{Similar stacking energetics in the presence but not absence of $\mathrm{Mg}^{2+}$}

We used NMR chemical shifts of A22-C8 and U23-C6, which are uniquely sensitive to coaxial stacking, to estimate the relative population of the unstacked and stacked states for the TAR variants in the absence and presence of $\mathrm{Mg}^{2+}$. The observed chemical shifts $\left(\delta_{\text {obs }}\right)$ for a given TAR variant is assumed to represent a population weighted average over the chemical shifts of the stacked $\left(\delta_{\text {stack }}\right)$ and unstacked $\left(\delta_{\text {unstack }}\right)$ conformations, such that $\delta_{\text {obs }}=$ $p_{\text {stack }} \delta_{\text {stack }}+p_{\text {unstack }} \delta_{\text {unstack }}$ and $p_{\text {stack }}+p_{\text {unstack }}=1$, where $p_{\text {stack }}$ and punstack are the fractional populations of stacked and unstacked states, respectively. $\delta_{\text {stack }}$ was obtained from fitting $\mathrm{Mg}^{2+}$-dependent CSPs in $\mathrm{U}_{7}$ TAR while $\delta_{\text {unstack }}$ was obtained from prior work based on fitting both $\mathrm{Mg}^{2+}$ and $\mathrm{Na}^{+}$CSPs in wtTAR (Casiano-Negroni et al. 2007). We then used the values of $\delta_{\text {obs, }}$ $\delta_{\text {stack, }}$ and $\delta_{\text {unstack }}$ to solve for $p_{\text {stack }}$ and Punstack for each TAR variant. Similar results were obtained when using $\delta_{\text {stack }}$ obtained from fitting CSPs to other bulge variants or the chemical shifts measured at $25 \mathrm{mM}$ $\mathrm{NaCl}$ with $25.6 \mathrm{mM} \mathrm{Mg}^{2+}$ for any bulge variant and when using the observed chemical shifts at $25 \mathrm{mM} \mathrm{NaCl}$ directly for wt, $U_{4}$, and $U_{7} T A R$ to represent $\delta_{\text {unstack }}$ (data not shown).

Similar populations were obtained when using U23-C6 or A22-C8 chemical shifts to estimate the populations, indicating that these resonances report on the same two-state conformational equilibrium. Based on these chemical shifts, the average population of the stacked state in $25 \mathrm{mM}$ $\mathrm{NaCl}$ without $\mathrm{Mg}^{2+}$ is estimated to be $72,73,21,9$, and $3 \%$ for $U_{1}, U_{2}$, wt, $\mathrm{U}_{4}$, and $\mathrm{U}_{7} T A R$, respectively. These values correspond to free energy 

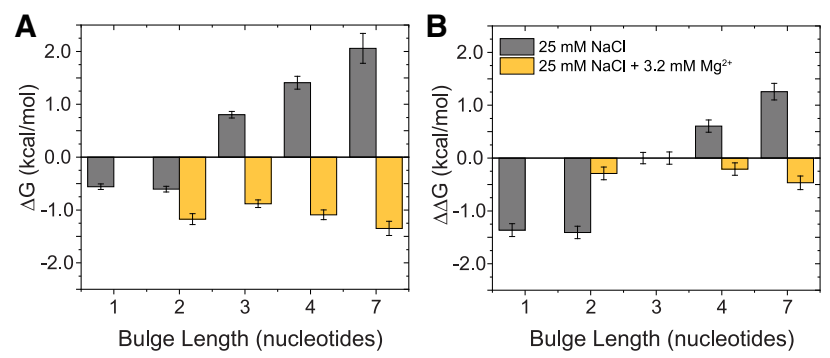

FIGURE 4. Energetics of interhelical coaxial stacking the TAR bulge variants. (A) Free energy differences between the stacked and unstacked states for each bulge variant $\left(\Delta G=G_{\text {stack }}-G_{\text {unstack }}\right)$ and (B) the relative free energy as compared to wtTAR where $\Delta \Delta \mathrm{G}=\Delta \mathrm{G}$ (variant) $-\Delta \mathrm{G}$ (wtTAR) at $25 \mathrm{mM} \mathrm{NaCl}$ (gray) and $25 \mathrm{mM} \mathrm{NaCl}+3.2$ $\mathrm{mM} \mathrm{Mg}^{2+}$ (gold). Error bars represent an estimated error due to imprecise chemical shift measurements, which was estimated to be $\sim 0.02$ ppm for ${ }^{13} \mathrm{C}$.

differences of coaxial stacking ( $\Delta \mathrm{G}=\mathrm{G}_{\text {stack }}-\mathrm{G}_{\text {unstack }}$ ) ranging between -0.61 and 2.25 (Fig. 4A). The differences in interhelical stacking energetics relative to wtTAR $[\Delta \Delta \mathrm{G}=$ $\Delta \mathrm{G}$ (variant) $-\Delta \mathrm{G}($ wtTAR) $]$ are $-1.39,-1.43,0.61,1.18$ $\mathrm{kcal} / \mathrm{mol}$ for $\mathrm{U}_{1}, \mathrm{U}_{2}, \mathrm{U}_{4}$, and $\mathrm{U}_{7} T A R$, respectively (Fig. 4B). As expected, the population of the stacked state decreases for longer bulges. This is most likely due to (i) growing electrostatic repulsion in and around the bulge with increasing bulge length in the stacked conformation, and (ii) there is a greater entropic penalty accompanying stacking with increasing bulge length as the number of unstacked conformations is expected to grow more rapidly than the number of stacked conformation with increasing bulge length (Bailor et al. 2011b; Mustoe et al. 2012). However, there are complexities in the changes in stacking energetics. We observe little to no change in the stacking energetics between $U_{1}$ and $U_{2} T A R(\Delta \Delta G=0.04 \mathrm{kcal} / \mathrm{mol})$, and removing a single nt from wtTAR stabilizes stacking to an extent $(\Delta \Delta \mathrm{G}=-1.43 \mathrm{kcal} / \mathrm{mol})$ that is greater than the destabilizing effects observed when adding four bulge nts to wtTAR $(\Delta \Delta \mathrm{G}=1.18 \mathrm{kcal} / \mathrm{mol})$.

The same analysis based on a two-state model reveals that the population of the stacked state in the presence of $3.2 \mathrm{mM} \mathrm{Mg}^{2+}$ increases to $88 \%, 82 \%, 86 \%, 91 \%$ for $\mathrm{U}_{2}$, wt, $\mathrm{U}_{4}$, and $\mathrm{U}_{7} T A R$, respectively (Fig. 4A). This lowers the difference in interhelical stacking energetics relative to wtTAR $(\Delta \Delta \mathrm{G})$ to $-0.29,-0.21,-0.45 \mathrm{kcal} / \mathrm{mol}$ for $U_{2}$, $\mathrm{U}_{4}$, and $\mathrm{U}_{7}$ TAR (Fig. 4B). Therefore, $\mathrm{Mg}^{2+}$ significantly reduces the dependence of stacking energetics on bulge length. It is likely that $\mathrm{Mg}^{2+}$ effectively diminishes electrostatic repulsion in the stacked state for the various conformations of the bulge residues, thereby lowering the energetic differences with different length bulges. In addition, $\mathrm{Mg}^{2+}$ may also help increase the number of conformations of the helices that are sampled in the stacked state with increasing bulge length, as we show below.

\section{NMR RDCs and resonance intensities support $\mathrm{Mg}^{2+}$-dependent interhelical stacking}

We used NMR residual dipolar couplings (RDCs) (Tjandra and Bax 1997; Tolman et al. 2001) to further test and characterize the $\mathrm{Mg}^{2+}$-dependent stacking transition in the TAR variants. RDCs measured between two nuclei provide long-range information regarding the orientation of the internuclear vector and the applied magnetic field as given by

$$
\left\langle\frac{1-3 \cos ^{2} \theta}{2}\right\rangle
$$

where $\theta$ is the angle between internuclear bond vector and the applied magnetic field, and the angular bracket denotes a time average over all orientations sampled in solution (Fürtig et al. 2003; Pitt et al. 2005; Bailor et al. 2010; Zhao and Zhang 2015). RDCs can be used to obtain information regarding the orientation and dynamics of molecular fragments such as the A-form helices in RNA over a broad range of timescales (<msec) (Tolman et al. 2001; AlHashimi et al. 2002; Musselman et al. 2006; Bailor et al. 2007; Getz et al. 2007). They can also provide insights into the local dynamics of bulges (Getz et al. 2007; Sun et al. 2007) and other RNA motifs (Eichhorn and AlHashimi 2014). We previously reported the RDC-based conformational analysis of wtTAR (Dethoff et al. 2008) and $\mathrm{U}_{2}$ TAR (Merriman et al. 2016) at $25 \mathrm{mM} \mathrm{NaCl}$, in the absence of $\mathrm{Mg}^{2+}$ and for wtTAR in the presence of $\mathrm{Mg}^{2+}$ (Al-Hashimi et al. 2003; Casiano-Negroni et al. 2007). Here, we measured RDCs for $U_{1}$ and $U_{7} T A R$ in $25 \mathrm{mM}$ $\mathrm{NaCl}$, in the absence of $\mathrm{Mg}^{2+}$ and $U_{1}$, wt, and $U_{7} T A R$ in $25 \mathrm{mM} \mathrm{NaCl}$ and $3 \mathrm{mM} \mathrm{Mg}^{2+}$ (Supplemental Fig. 5A; Supplemental Tables 3, 4). Measurements under saturating $\mathrm{Mg}^{2+}$ concentrations were not feasible due to the incompatibility of these conditions with the Pf1-phage alignment medium used to measure RDCs. Based on the $\mathrm{Mg}^{2+}$-dependent CSPs for U23-C6 and A22-C8, the population of the stacked state is predicted to be $88 \%-90 \%$, for both wt, and $U_{7} T A R$ at $25 \mathrm{mM} \mathrm{NaCl}$ and $3 \mathrm{mM} \mathrm{Mg}^{2+}$. This can be compared to $\sim 20 \%, \sim 3 \%$ for wt and $U_{7}$, respectively, in the absence of $\mathrm{Mg}^{2+}$. Such a significant $\mathrm{Mg}^{2+}$-dependent shift toward the stacked ensemble should be readily measurable using RDCs, which are exquisitely sensitive to global interhelical conformation (Tolman et al. 1997; Casiano-Negroni et al. 2007; Zhang et al. 2007).

In the absence of $\mathrm{Mg}^{2+}$, bulge residues exhibited small RDCs (Supplemental Fig. 5B) and high resonance intensities in 2D HSOC spectra (Supplemental Fig. 2A) consistent with a high degree of local flexibility, with $U_{1} T A R$ and $\mathrm{U}_{2} \mathrm{TAR}$ exhibiting greater flexibility than the longer bulges most likely due to the flipping out of U23 (Merriman et al. 2016). The RDCs measured throughout wt and $U_{7} T A R$ in the presence of $3 \mathrm{mM} \mathrm{Mg}^{2+}$ differed significantly from counterparts measured in the absence of $\mathrm{Mg}^{2+}$, consistent 
with $\mathrm{Mg}^{2+}$ inducing a global change in the structure and/or dynamics of these TAR variants (Fig. 5A). In contrast, similar RDCs were measured for $U_{1} T A R$ in the presence or absence of $\mathrm{Mg}^{2+}$, strongly suggesting $\mathrm{Mg}^{2+}$ does not significantly alter the $U_{1}$ TAR conformation (Fig. 5A). In all other cases, we observed a decrease in the magnitude of bulge RDCs in $3 \mathrm{mM} \mathrm{Mg}^{2+}$ as compared to bulge RDCs at $25 \mathrm{mM} \mathrm{NaCl}$, which is consistent with a shift toward the flipped out flexible conformation expected in the stacked state (Supplemental Fig. 5C; Tolman et al. 2001; Merriman et al. 2016). This conclusion is also supported by another independent measurement of flexibility at the bulge resonances using intensity measurements on 2D NMR spectra (Zhang et al. 2006; Getz et al. 2007; Sun et al. 2007) (see Materials and Methods). Higher resonance intensities, which are indicative of extensive motions on the picosecond to nanosecond timescale, are observed for the bulge residues in the presence of $\mathrm{Mg}^{2+}$
A
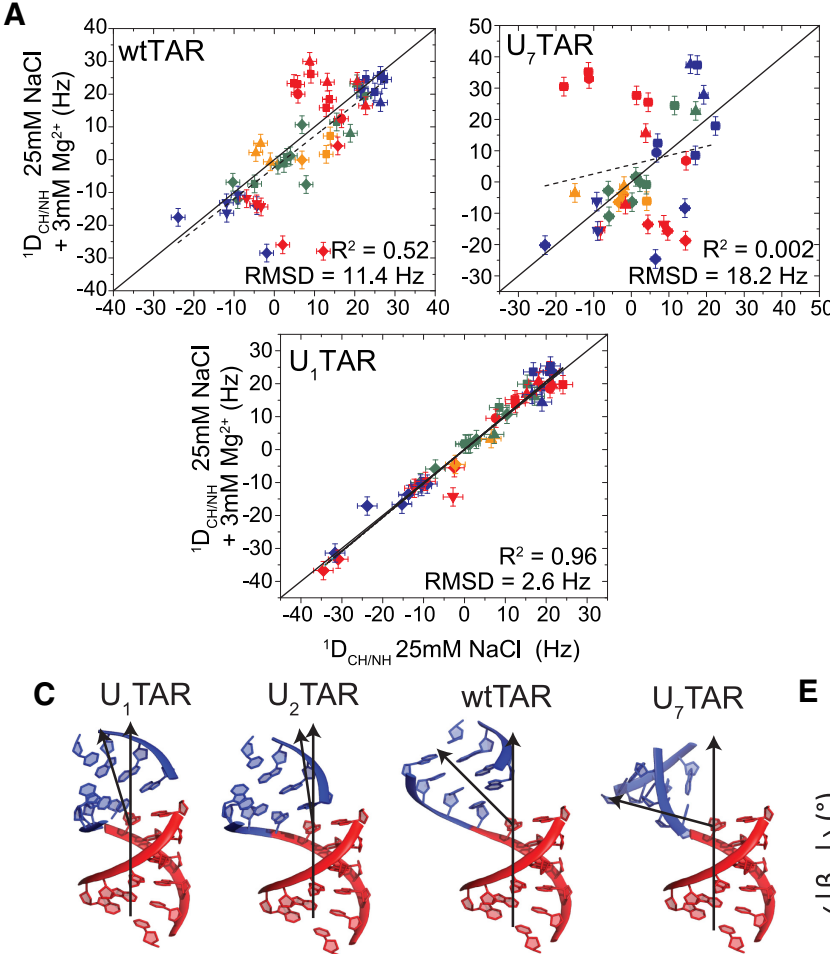

$\left\langle\left|\beta_{\mathrm{h}}\right|\right\rangle=17 \pm 7^{\circ}$

$\theta_{\text {int }}=0.90 \pm 0.05$

D

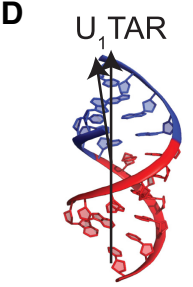

$\left\langle\beta_{h} \mid\right\rangle=10 \pm 6^{\circ}$

$\theta_{\text {int }}=0.90 \pm 0.07$

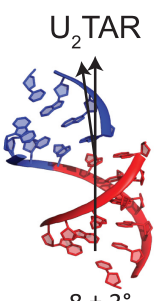

$8 \pm 3^{\circ}$

$8 \pm 3^{\circ}$
$0.75 \pm 0.07$

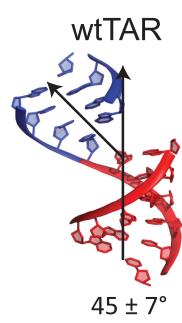

$0.54 \pm 0.07$

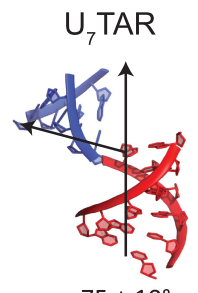

$75 \pm 10^{\circ}$
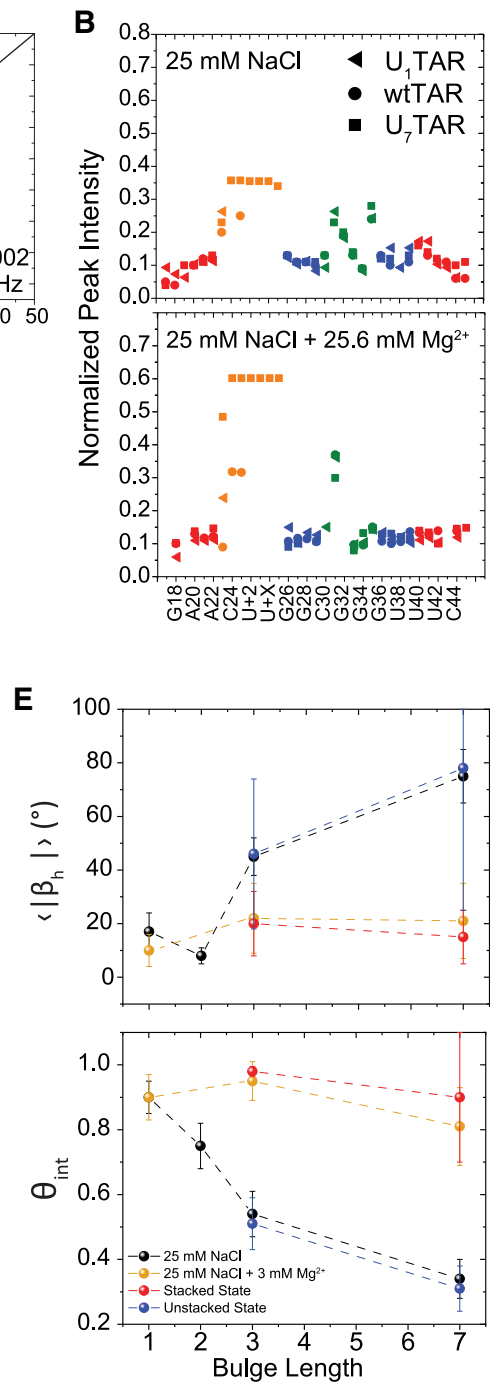

FIGURE 5. Characterizing the interhelical structure and dynamics of the TAR bulge variants using NMR. (A) Comparison of RDCs measured at $25 \mathrm{mM} \mathrm{NaCl}$ and $25 \mathrm{mM} \mathrm{NaCl}$ and $3 \mathrm{mM} \mathrm{Mg}^{2+}$ for wt, $\mathrm{U}_{7}$, and $\mathrm{U}_{1}$ TAR. RDCs were normalized to the alignment of wtTAR at $25 \mathrm{mM} \mathrm{NaCl}$ (see Materials and Methods). RDC values are color coded to represent the part of the molecule measurements that were made: helix 1 (red), helix 2 (blue), apical loop (green), and bulge (orange), whereas symbols represent the bond vector: $\mathrm{C}_{8} \mathrm{H}_{8} / \mathrm{C}_{6} \mathrm{H}_{6}$ (square), $\mathrm{C}_{2} \mathrm{H}_{2}\left(\right.$ circle), $\mathrm{C}_{1}{ }^{\prime} \mathrm{H}_{1}{ }^{\prime}$ (diamond), $\mathrm{C}_{5} \mathrm{H}_{5}$ (triangle), and $\mathrm{N}_{1} \mathrm{H}_{1} / \mathrm{N}_{3} \mathrm{H}_{3}$ (downward triangle). Error bars represent the estimated error of RDC measurements (see Materials and Methods). (B) Normalized peak intensities (see Materials and Methods) measured in $U_{1}$, wt, and $U_{7} T A R$ at $25 \mathrm{mM} \mathrm{NaCl}$ (bottom) and $25 \mathrm{mM} \mathrm{NaCl}+25.6 \mathrm{mM}$ $\mathrm{Mg}^{2+}$ (top). See inset for legend. The average interhelical conformation of wtTAR, $U_{1}, U_{2}$, and $U_{7}$ bulge variants with helix 1 in red, and helix 2 in blue measured at (C) $25 \mathrm{mM} \mathrm{NaCl}$ without $\mathrm{Mg}^{2+}$ and (D) $25 \mathrm{mM} \mathrm{NaCl}$ and $3 \mathrm{mM} \mathrm{Mg}^{2+}$. The average bend angle $\left(\left\langle\left|\beta_{\mathrm{h}}\right|\right\rangle\right)$ and $\vartheta_{\text {int }}$ is shown for each structure. $(E)\left\langle\left|\beta_{h}\right|\right\rangle$ and $\vartheta_{\text {int }}$ as a function of bulge length for TAR variants in $25 \mathrm{mM} \mathrm{NaCl}$ without $\mathrm{Mg}^{2+}$ (gray) and $25 \mathrm{mM} \mathrm{NaCl}$ and $3 \mathrm{mM} \mathrm{Mg}{ }^{2+}$ (gold). RDC derived values of $\left\langle\left|\beta_{h}\right|\right\rangle$ and $\vartheta_{\text {int }}$ for the interhelical coaxially stacked (red) and unstacked (blue) state of wt and $U_{7} T A R$ are also shown. Error bars represent the propagated error in $\left\langle\left|\beta_{h}\right|\right\rangle$ and $\vartheta_{\text {int }}$ as determined using AFORM-RDC (see Table 1; Musselman et al. 2006). 
as compared to resonance intensities at $25 \mathrm{mM} \mathrm{NaCl}$ (Fig. 5B; Supplemental Fig. 2B).

\section{Insights into interhelical ensembles from order tensor analysis of RDCs}

To characterize the interhelical ensemble in the presence and absence of $\mathrm{Mg}^{2+}, \mathrm{RDC}$ measured in each helix were subjected to an order tensor analysis (Losonczi et al. 1999; Tolman et al. 2001; Hansen and Al-Hashimi 2006). In this analysis, the average orientation of helices is obtained by superimposing the order tensor frame of each helix, which describes how the helix aligns relative to the applied magnetic field in the presence of an ordering medium (Table 1; Supplemental Fig. 6A-C). The amplitude of interhelical motions is computed from the ratio of the generalized degree of order $\left(\boldsymbol{\vartheta}_{\text {int }}=\boldsymbol{\vartheta}_{\mathrm{i}} / \boldsymbol{\vartheta}_{\mathrm{j}} ; \boldsymbol{\vartheta}_{\mathrm{i}}<\boldsymbol{\vartheta}_{\mathrm{j}}\right)$ describing the degree of helix alignment relative to the applied magnetic field (Tolman et al. 2001). The $\vartheta_{\text {int }}$ value ranges between 1 for interhelical rigidity and 0 for maximum interhelical motions. Because of possible coupling between helix motions and overall alignment (Zhang et al. 2006), the $\vartheta_{\text {int }}$ value will generally underestimate the motional amplitudes (Al-Hashimi et al. 2002; Zhang et al. 2003).

Figure $5 \mathrm{C}$ shows the RDC-derived average interhelical orientation for bulge variants in the absence of $\mathrm{Mg}^{2+}$. Consistent with prior studies using TEB (Zacharias and Hagerman 1995a) and FRET (Gohlke et al. 1994), increasing the bulge length from 1 to 7 nts resulted in a gradual increase in the interhelical bend angle $\left(\left|\beta_{h}\right|\right)$ from $17 \pm 7^{\circ}$ to $75 \pm 10^{\circ}$ (Table 1). Consistent with the CSP data (Fig. $2 \mathrm{~B})$, a sharp transition was observed between $\mathrm{U}_{2}$ and wtTAR, which is again biased toward the interhelical coaxial conformation $\left(\left|\beta_{h}\right|=8\right.$ and $45^{\circ}$ for $U_{2}$ and wtTAR, respectively). The increase in the average bend angle with bulge length was accompanied by an increase in the amplitude of interhelical motions as the RDC-derived $\vartheta_{\text {int }}$ decreased from $0.90 \pm 0.05$ in $U_{1} T A R$ to $0.34 \pm 0.06$ in $U_{7} T A R$. Here, $\mathrm{U}_{2} T A R$ follows the linear trend formed by the other TAR variants. Therefore, in the absence of $\mathrm{Mg}^{2+}$, increasing the bulge length increases the interhelical flexibility and biases the ensemble toward more kinked conformations.

A similar order analysis of the RDCs (Table 1; Supplemental Fig. 6D) shows that for both wtTAR and $\mathrm{U}_{7} \mathrm{TAR}, \mathrm{Mg}^{2+}$ shifts the equilibrium toward the more linear and rigid stacked state (Fig. 5D). The average bend angle decreased from $45 \pm 7^{\circ}$ and $75 \pm 10^{\circ}$ in the absence of $\mathrm{Mg}^{2+}$ to $22 \pm 13^{\circ}$ and $21 \pm 14^{\circ}$ in the presence of $3 \mathrm{mM}$ $\mathrm{Mg}^{2+}$, respectively. Similarly, the $\vartheta_{\text {int }}$ value increased from $0.54 \pm 0.07$ and $0.34 \pm 0.06$ in the absence of $\mathrm{Mg}^{2+}$ to $0.95 \pm 0.06$ and $0.81 \pm 0.12$ in the presence of $3 \mathrm{mM}$ $\mathrm{Mg}^{2+}$ (Fig. 5E). In contrast, similar order tensor parameters were obtained for $U_{1} T A R$ under the different salt conditions, again supporting the absence of an $\mathrm{Mg}^{2+}$-induced conformational transition. The fact that the RDC derived interhelical behavior tracks with the CSPs helps to confirm that the A22 and U23 CSPs faithfully report on the stacking transition.

TABLE 1. Order tensor analysis statistics for $U_{1} T A R, U_{2} T A R$ (Merriman et al. 2016), wtTAR (Dethoff et al. 2008), and $U_{7} T A R$

\begin{tabular}{|c|c|c|c|c|c|c|c|c|c|c|}
\hline & & $N$ & RMSD $(\mathrm{Hz})$ & $\mathrm{CN}$ & $\mathrm{R}$ & $\eta$ & $\vartheta\left(\times 10^{-3}\right)$ & $\vartheta_{\text {int }}$ & $\beta_{\mathrm{h}}\left({ }^{\circ}\right)$ & $\xi\left({ }^{\circ}\right)$ \\
\hline $\mathrm{U}_{1} \mathrm{TAR}$ & $\begin{array}{l}\text { Helix } 1 \\
\text { Helix } 2\end{array}$ & $\begin{array}{r}11 \\
9\end{array}$ & $\begin{array}{l}2.7 \\
2.4\end{array}$ & $\begin{array}{l}2.7 \\
3.6\end{array}$ & $\begin{array}{l}0.99 \\
0.99\end{array}$ & $\begin{array}{l}0.19 \pm 0.1 \\
0.18 \pm 0.08\end{array}$ & $\begin{array}{l}1.14 \pm 0.04 \\
1.27 \pm 0.04\end{array}$ & $0.90 \pm 0.05$ & $-17 \pm 7$ & $6 \pm 50$ \\
\hline $\mathrm{U}_{2} \mathrm{TAR}^{\mathrm{a}}$ & $\begin{array}{l}\text { Helix } 1 \\
\text { Helix } 2\end{array}$ & $\begin{array}{l}11 \\
11\end{array}$ & $\begin{array}{l}2.5 \\
1.5\end{array}$ & $\begin{array}{l}4.4 \\
5.9\end{array}$ & $\begin{array}{l}0.99 \\
0.99\end{array}$ & $\begin{array}{l}0.59 \pm 0.15 \\
0.14 \pm 0.09\end{array}$ & $\begin{array}{l}1.4 \pm 0.1 \\
1.9 \pm 0.1\end{array}$ & $0.75 \pm 0.07$ & $-8 \pm 3$ & $23 \pm 50$ \\
\hline $\mathrm{TAR}^{\mathrm{a}}$ & $\begin{array}{l}\text { Helix } 1 \\
\text { Helix } 2\end{array}$ & $\begin{array}{l}14 \\
13\end{array}$ & $\begin{array}{l}1.2 \\
1.7\end{array}$ & $\begin{array}{l}5.7 \\
3.0\end{array}$ & $\begin{array}{l}0.99 \\
0.99\end{array}$ & $\begin{array}{l}0.36 \pm 0.10 \\
0.10 \pm 0.05\end{array}$ & $\begin{array}{l}0.65 \pm 0.08 \\
1.19 \pm 0.05\end{array}$ & $0.54 \pm 0.07$ & $45 \pm 7$ & $-41 \pm 50$ \\
\hline $\mathrm{U}_{7} \mathrm{TAR}$ & $\begin{array}{l}\text { Helix } 1 \\
\text { Helix } 2\end{array}$ & $\begin{array}{r}10 \\
8\end{array}$ & $\begin{array}{l}2.9 \\
2.3\end{array}$ & $\begin{array}{l}4.7 \\
7.0\end{array}$ & $\begin{array}{l}0.99 \\
0.99\end{array}$ & $\begin{array}{l}0.77 \pm 0.22 \\
0.75 \pm 0.07\end{array}$ & $\begin{array}{l}1.02 \pm 0.04 \\
2.98 \pm 0.13\end{array}$ & $0.34 \pm 0.06$ & $75 \pm 10^{b}$ & $57 \pm 50$ \\
\hline $\mathrm{U}_{1}$ TAR $3 \mathrm{mM} \mathrm{Mg}^{2+}$ & $\begin{array}{l}\text { Helix } 1 \\
\text { Helix } 2\end{array}$ & $\begin{array}{l}10 \\
13\end{array}$ & $\begin{array}{l}2.1 \\
2.7\end{array}$ & $\begin{array}{l}5.6 \\
4.2\end{array}$ & $\begin{array}{l}0.99 \\
0.98\end{array}$ & $\begin{array}{l}0.33 \pm 0.1 \\
0.20 \pm 0.07\end{array}$ & $\begin{array}{l}1.05 \pm 0.04 \\
1.16 \pm 0.06\end{array}$ & $0.90 \pm 0.07$ & $10 \pm 6$ & $24 \pm 50$ \\
\hline TAR $3 \mathrm{mM} \mathrm{Mg}^{2+}$ & $\begin{array}{l}\text { Helix } 1 \\
\text { Helix } 2\end{array}$ & $\begin{array}{l}13 \\
11\end{array}$ & $\begin{array}{l}2.7 \\
2.6\end{array}$ & $\begin{array}{l}2.9 \\
3.2\end{array}$ & $\begin{array}{l}0.99 \\
0.99\end{array}$ & $\begin{array}{l}0.16 \pm 0.08 \\
0.13 \pm 0.09\end{array}$ & $\begin{array}{l}1.15 \pm 0.06 \\
1.22 \pm 0.05\end{array}$ & $0.95 \pm 0.06$ & $22 \pm 13$ & $9 \pm 50$ \\
\hline 7U-TAR $3 \mathrm{mM} \mathrm{Mg}^{2+}$ & $\begin{array}{l}\text { Helix } 1 \\
\text { Helix } 2\end{array}$ & $\begin{array}{l}11 \\
15\end{array}$ & $\begin{array}{l}2.2 \\
2.8\end{array}$ & $\begin{array}{l}3.0 \\
3.3\end{array}$ & $\begin{array}{l}0.99 \\
0.98\end{array}$ & $\begin{array}{l}0.86 \pm 0.1 \\
0.47 \pm 0.07\end{array}$ & $\begin{array}{l}0.72 \pm 0.08 \\
0.88 \pm 0.08\end{array}$ & $0.81 \pm 0.12$ & $21 \pm 14$ & $7 \pm 50$ \\
\hline
\end{tabular}

aPreviously reported RDC measurements.

${ }^{b}$ Error could not be accurately reported from AFORM-RDC and was estimated from Sanson-Flamsteed projections of helical order tensors (Supplemental Fig. 6C).

Reported parameters are the number of input RDCs (N), root-mean-square deviation (RMSD) and Pearson's correlation coefficient (R) between measured and back-calculated RDCs; condition number $(\mathrm{CN})$ describing the independents of the RDC data; degree of asymmetry $\left(\eta, \eta=\left|S_{y y}-S_{x x}\right| / S_{z z}\right)$; generalized degree of $\operatorname{order}\left(\vartheta, \sqrt{2 / 3[S]} \vartheta=\sqrt{2 / 3\left[S_{x x}^{2}+S_{y y}^{2}+S_{z z}^{2}\right.}\right)$ (Tolman et al. 2001). Also shown are the internal generalized degree of order $\left(\vartheta_{\text {int }}, \vartheta_{\text {int }}=\vartheta_{\mathrm{i}} / \vartheta_{\mathrm{ii}} ; \boldsymbol{\vartheta}_{\mathrm{i}}<\right.$ $\left.\vartheta_{\mathrm{ii}}\right)$, and the average interhelical bend $\left(\beta_{h}\right)$ and twist $\left(\xi_{h}\right)$ (see Materials and Methods). Errors were estimated using AFORM-RDC (Musselman et al. 2006). 


\section{$\mathrm{U}_{2} \mathrm{TAR}$ is biased toward linear conformations in the presence and absence of $\mathbf{M g}^{2+}$}

The average bend angle for $\mathrm{U}_{2} T A R$ in the presence or $a b$ sence of $\mathrm{Mg}^{2+}$ is lower than that of any other bulge variant, including $U_{1} T A R$ (Table 1 ). Such a bias toward more linear conformations was not observed in prior TEB studies of $A$ and $U$ dinucleotide bulges, indicating that it is potentially unique to TAR (Zacharias and Hagerman 1995a). We observe unique NOEs between $\mathrm{G} 26-\mathrm{H} 1^{\prime}$ and U23-H6, A22-H8, and U25-H6 in $\mathrm{U}_{2} T A R$, but not wtTAR, which suggests a potentially unique bulge conformation in which U23 forms a U23•A27•U38 base triple (Supplemental Fig. 7A). This base triple is observed in $U_{2}$ and wtTAR when complexed with mimics of the HIV viral protein Tat (Puglisi et al. 1992; Brodsky and Williamson 1997; Hennig and Williamson 2000). Indeed, a molecular dynamics (MD) simulation and a structure-based survey suggest that such an interaction could occur in $U_{2} T A R$ (Supplemental Material Discussion, Supplemental Fig. 7). Thus, the 2 nt bulge in $U_{2}$ TAR may be short enough to promote stacking but long enough to allow base triple formation.

To test this hypothesis, we collected H6(C5)NN NMR spectra (Pitt et al. 2004) to directly probe for $\mathrm{H}$-bonding between $\mathrm{U} 23-\mathrm{N} 3$ and $\mathrm{A} 22-\mathrm{N} 7$ in $\mathrm{U}_{2} T A R$ at $25 \mathrm{mM} \mathrm{NaCl}$ in the absence or presence of $3 \mathrm{mM} \mathrm{Mg}^{2+}$ (Supplemental Fig. 7F). Results revealed that U23-N3 is not hydrogen bonded to A27-N7, and thus is not stably forming a base triple under either buffer condition. However, weak hydrogen bonding between A22 and U40 was observed at $25 \mathrm{mM} \mathrm{NaCl}$ (Supplemental Fig. 7F). This H-bond is not observed in wtTAR (Pitt et al. 2004). Stronger hydrogen bonding of the flanking A22-U40 base pair, as compared to wtTAR, coupled with conformational changes in the bulge may result in stronger stacking interactions between helices and thus a smaller interhelical bend in $U_{2} T A R$. Assuming negligible line broadening due to conformational exchange, it should have been possible to detect a base triple using the $\mathrm{H} 6(\mathrm{C} 5) \mathrm{NN}$ NMR experiment even if its population was as low as $\sim 10 \%$. On the other hand, the base triple may be forming with significant population $>10 \%$ but is not detectable because of unfavorable exchange kinetics that may lead to unfavorable line broadening. Future studies could explore other trans-hydrogen bond scalar coupling experiments (Hennig and Williamson 2000) to examine whether such lowly populated base triple species form and to examine how their stability and dynamics vary across bulge lengths.

\section{Evidence for increased dynamics in the stacked state with longer bulges}

We can estimate $\vartheta_{\text {int }} / \beta_{\mathrm{h}}$ values of $0.98 \pm 0.15 / 20 \pm 12^{\circ}$ and $0.90 \pm 0.20 / 15 \pm 10^{\circ}$ for the stacked state of wt and
$U_{7}$ TAR based on the population of the stacked $\left(p_{\text {stack }}\right)$ and unstacked ( $p_{\text {unstack}}$ ) state derived from the $\mathrm{Mg}_{1 / 2}$ values, approximate interhelical parameters for the unstacked states deduced at low salt concentration, and assuming that the measured bend angles and $\boldsymbol{\vartheta}_{\text {int }}$ values correspond to population-weighted averages (i.e., $\vartheta_{\text {int,obs }}=p_{\text {stack }} \vartheta_{\text {int,stacked }}+p_{\text {unstack }} \vartheta_{\text {int, unstackedi }} \beta_{\text {h,obs }}=$ $\left.p_{\text {stacked }} \beta_{\mathrm{h} \text {,stacked }}+p_{\text {unstacked }} \beta_{\mathrm{h} \text {, unstacked }}\right)$. This can be compared to $0.51 \pm 0.08 / 46 \pm 28^{\circ}$ and $0.31 \pm 0.07 / 78 \pm 53^{\circ}$ for the corresponding unstacked state, respectively. Interestingly, we find a greater degree of interhelical flexibility in the stacked state of $U_{7} T A R$ as compared to wtTAR although these differences are within error. Additional evidence for increased flexibility in stacked state in the presence of $\mathrm{Mg}^{2+}$ with increasing bulge length comes from the higher resonance intensities at both base and sugar resonances belonging to residues in and around the bulge (Fig. 5B; Supplemental Fig. 2B).

Taken together, these NMR data provide strong evidence that $\mathrm{U}_{2}$, wt, and $\mathrm{U}_{7}$ TAR but not $\mathrm{U}_{1} T A R$ undergo an $\mathrm{Mg}^{2+}$-dependent stacking transition and that elongating the bulge results in an increase in the dynamics in both the unstacked and coaxially stacked conformations.

\section{DISCUSSION}

Early studies showed that the kinks introduced by bulges decrease with decreasing bulge length and increasing salt concentration (Lilley 1995; Zacharias and Hagerman 1995a). Subsequent NMR studies on HIV-1 TAR (AlHashimi et al. 2003; Casiano-Negroni et al. 2007) as well as the two bulge variant (Merriman et al. 2016) indicated that poly-pyrimidine bulges exist in a dynamic equilibrium between stacked and unstacked conformations with $\mathrm{Mg}^{2+}$ favoring the stacked state. Our results show that other TAR variants with $n \geq 2$ can be described by a similar two-state dynamic equilibrium. Conversely, $U_{1} T A R$ did not undergo an $\mathrm{Mg}^{2+}$-induced transition. Prior RDC studies showed that $\mathrm{Mg}^{2+}$ minimally affects the global conformation of RNase P P4 RNA containing a single bulge (Getz et al. 2007). This similarity indicates that the absence of an $\mathrm{Mg}^{2+}$-dependent transition is not unique to $U_{1} T A R$ and may be a general feature of single-pyrimidine bulges.

In the X-ray structure of wtTAR (Ippolito and Steitz 1998), some of the metal interactions rely on contacts with more than one bulge nt, interactions that could not be supported in $U_{1} T A R$. Indeed, unlike wt and $U_{7} T A R, U_{1} T A R$ did not exhibit large $\mathrm{Mg}^{2+}$ CSPs at purine-N7, which frequently forms contacts with metals (Supplemental Fig. 8). The shorter bulge in $U_{1}$ TAR may also preclude optimal interhelical stacking and/or may form more stable alternative structures. A crystal structure of an RNA duplex containing a single uridine bulge shows a highly stable structure, in which the uridine bulge folds back to hydrogen bond to flanking residues in the minor groove (Xiong et al. 2001). 
The uridine bulge causes over-twisting between flanking bps and the single bound $\mathrm{Ca}^{2+}$ ions near the bulge appear to be disordered. Together these works support our findings of a highly stable structure of $U_{1} T A R$ that is minimally perturbed by divalent metal ions.

Increasing the bulge length from 1 to $7 \mathrm{nts}$ resulted in an increase in both the average kink angle as well as the degree of interhelical flexibility in both the stacked and unstacked conformations. Yet despite this significant difference, the TAR variants showed similar energetics for the stacking transition in the presence of $\mathrm{Mg}^{2+}$, with differences of $0.4 \mathrm{kcal} / \mathrm{mol}$, compared to differences upwards of $\sim 2.9 \mathrm{kcal} / \mathrm{mol}$ in low monovalent salt. One plausible explanation supported by our NMR data is that in the presence of $\mathrm{Mg}^{2+}$, the stacked state is not rigid, but rather retains a degree of conformational flexibility, possibly involving twisting motions and bending motions that maintain stacking as well as localized flexibility within the bulge itself. Indeed, prior studies have shown that $\mathrm{Mg}^{2+}$ activates dynamics (Chu et al. 2009; Herschlag et al. 2010; Chen et al. 2012; Shi et al. 2015; Bao et al. 2016). These motions could be restricted in the absence of $\mathrm{Mg}^{2+}$ because electrostatic repulsion between the closely stacked helices limits the range of conformations sampled. However, we cannot rule out other contributions. For example, longer bulges may provide more flexibility to form optimal stacking interactions that are otherwise topologically inaccessible to shorter bulges. While the different bulge variants show similar helical chemical shifts at saturating $\mathrm{Mg}^{2+}$ conditions, there are notable differences at residues near the bulge that suggest differences in the stacked ensemble. The longer bulges may also interact more favorably with $\mathrm{Mg}^{2+}$ ions. Further studies are needed to dissect these different energetic contributions. Finally, while unlikely given prior studies showing that UCU and UUU bulge behave similarly (Roy et al. 1990; SumnerSmith et al. 1991; Riordan et al. 1992; Carter-O'connell et al. 2008), we cannot rule out sequence effects on the behavior of wtTAR relative to poly(U) bulge variants. Future studies should also examine how sequence composition affects the conformational behavior of bulge motifs (Eichhorn and Al-Hashimi 2014).

Our work provides detailed conformational, dynamic and energetic information yet there are, as we note, atomic-level uncertainties. We previously showed that the interhelical behavior of the TAR ensemble is difficult to model using MD simulations (Eichhorn et al. 2012; Salmon et al. 2013; Yang et al. 2014). The rich data set obtained in this work can provide powerful opportunities to develop and test atomic-level MD force field energetics. Systematic data sets such as the one presented here will ultimately be needed to fully understand the forces underlying RNA energetics and dynamics.

The picture that emerges from this study is that under near-physiological (3 mM) $\mathrm{Mg}^{2+}$, poly-pyrimidine bulges exist predominantly (population $>90 \%$ ) in the stacked state, with the population of stacked state decreasing minimally between 1 and 7 bulge motifs. However, the interhelical flexibility of the stacked state ensemble increases with increasing bulge length, possibly allowing a broader range of conformations to be sampled while simultaneously compensating for the entropy loss accompanying stacking. This ability to sample unstacked conformations is important when considering that most helices are coaxially stacked in naked RNA structures but deviate significantly from coaxial when in complex with proteins and ligands (Fig. 1A). Energetically compensated transitions between states that retain varying degrees and/or types of flexibility may be a common feature of RNA junctions that helps to maximize adaptability and malleability of these motifs for optimally effecting changes in response to cellular cues.

\section{MATERIALS AND METHODS}

\section{Sample preparation}

\section{In vitro transcription}

RNA NMR samples were prepared by in vitro transcription using T7 RNA polymerase (Fisher Scientific), uniformly labeled ${ }^{13} \mathrm{C} /$ ${ }^{15} \mathrm{~N}$ nucleotides (Cambridge Isotopes Laboratories, Inc.), and synthetic DNA templates (Integrated DNA Technologies), which contain the T7 promoter sequence (TTAATACGACTCACTATA) and RNA sequence. Samples were purified with denaturing, $8 \mathrm{M}$ Urea and $1 \times$ tris-borate-EDTA, polyacrylamide gel electrophoresis (PAGE). RNA was excised after briefly shadowing the gel at 365 nm using a UV handlamp, followed by electro elution (Whatman, GE Healthcare) in $1 \times$ tris-acetic acid-EDTA. The eluted RNA was concentrated followed by ethanol precipitation. The RNA was then annealed by heating to $95^{\circ} \mathrm{C}$ for 5-10 min and snap-cooled on ice for $1 \mathrm{~h}$. Finally, samples were buffer exchanged using centrifugal concentration into NMR buffer $(15 \mathrm{mM}$ sodium phosphate, $25 \mathrm{mM} \mathrm{NaCl}, 0.1 \mathrm{mM}$ EDTA and $\mathrm{pH}^{\prime} \mathrm{d}$ to 6.4 using concentrated $12 \mathrm{M} \mathrm{HCl}$ or $5 \mathrm{M} \mathrm{NaOH}$ ). $10 \% \mathrm{D}_{2} \mathrm{O}$ was added to each sample before data were collected.

\section{Solid-phase oligonucleotide synthesis}

Unlabeled $U_{2}$ TAR used in 2D NOESY NMR experiments was synthesized with the MerMade 6 DNA/RNA synthesizer (Bioautomation) using standard phosphoramidite chemistry and base and 2'-hydroxyl deprotection protocols. Samples were purified using Glen-Pak RNA purification cartridges following product protocol which can be found online (www.glenresearch.com). After purification the RNA was ethanol precipitated, and buffer exchanged as described above.

\section{NMR experiments}

\section{Resonance assignments}

Resonance assignments for TAR variants were obtained by overlaying 2D HSOC spectra of TAR variants with spectra of 
wtTAR (Dethoff et al. 2008) and $U_{2}$ TAR (Merriman et al. 2016) as well as HCN experiments to confirm sugar and aromatic assignments (Supplemental Fig. 9). Experiments were processed using NMRPipe (Delaglio et al. 1995), and visualized in SPARKY (Goddard and Kneller, SPARKY 3, University of California, San Francisco).

\section{Measuring residual dipolar couplings}

One-bond $\mathrm{C}-\mathrm{H}$ splittings $\left({ }^{1} \mathrm{D}_{\mathrm{CH}}\right)$ in base $(\mathrm{C} 2 \mathrm{H} 2, \mathrm{C} 6 \mathrm{H} 6$, and $\mathrm{C} 8 \mathrm{H} 8)$ and sugar $\left(\mathrm{C}^{\prime} \mathrm{H}^{\prime}\right)$ moieties were measured with $2 \mathrm{D}{ }^{13} \mathrm{C}^{1}{ }^{1} \mathrm{H} \mathrm{S}^{3} \mathrm{E}$ HSQC experiments, which encode splittings in either the ${ }^{1} \mathrm{H}$ or ${ }^{13} \mathrm{C}$ dimension (Meissner and Sorensen 1999; Pitt et al. 2005). $\mathrm{N}-\mathrm{H}$ splittings $\left({ }^{1} \mathrm{D}_{\mathrm{NH}}\right)$ were measured using $2 \mathrm{D}{ }^{1} \mathrm{H} /{ }^{15} \mathrm{~N}$ HSOC experiments using spin-state selection, which encode splittings in the ${ }^{1} \mathrm{H}$ dimension (Parella 2006), and a decoupled 2D ${ }^{1} \mathrm{H} /{ }^{15} \mathrm{~N}$ $\mathrm{HSQC}$ was used to measure splittings in the ${ }^{15} \mathrm{~N}$ dimension. RDCs were calculated by taking the difference between splittings measured in the absence $(J)$ and presence $(J+D)$ of $15-23 \mathrm{mg} / \mathrm{mL}$ of Pf1 phage (Asla Biotech, Ltd.) aligning medium. The RDCs measured from the two sets of experiments were averaged and used in subsequent analyses (Supplemental Fig. 5A; Supplemental Tables 3, 4). The root-mean-square deviation (RMSD) between RDCs measured using splittings encoded in ${ }^{1} \mathrm{H}$ versus ${ }^{13} \mathrm{C} /{ }^{15} \mathrm{~N}$ dimension was used to estimate the RDC measurement uncertainty (Supplemental Fig. 5A). Data were collected on a $600 \mathrm{MHz}$ Bruker NMR spectrometer equipped with an HCN cryogenic probe for $U_{1}$ and $U_{7} T A R$ in NMR buffer, and $U_{7} T A R$ in NMR buffer with $3 \mathrm{mM} \mathrm{Mg}^{2+}$, and on a $700 \mathrm{MHz}$ Bruker NMR spectrometer equipped with a $5 \mathrm{mM}$ QXI room temperature quadrupolar probe $\left({ }^{1} \mathrm{H} /{ }^{19} \mathrm{~F} /{ }^{13} \mathrm{C} /{ }^{15} \mathrm{~N}\right)$ with $\mathrm{Z}$-axis pulse field gradients for $\mathrm{U}_{1}$ and wTTAR in NMR buffer with $3 \mathrm{mM} \mathrm{Mg}^{2+}$.

\section{Order tensor analysis of RDCs}

RDCs measured in nonterminal Watson-Crick base pairs (G18C44, C19-G43,A20-U42 in helix 1 and G26-C39, A27-U38, G28C37 in helix 2) were subjected to an order tensor analysis (Losonczi et al. 1999) using the program RAMAH (Hansen and Al-Hashimi 2006) as described previously (Losonczi et al. 1999; Bailor et al. 2007). The analysis used idealized A-form helices as the input structure for the two helices. The helices were created in Insight II (Molecular Simulations) correcting the propeller twist to $15^{\circ}$. Uncertainties in the best-fit order tensor were estimated with the program AFORM-RDC (Musselman et al. 2006). Average interhelical orientations were determined by rotating the input idealized A-form helix into the principal axis system (PAS) of the best-fit order tensor frame. Degeneracies in the structures (Prestegard et al. 2000) were then determined by visualizing helices in PyMOL (http://www.pymol.org) where helix 2 was superimposed onto helix 1 . Helices were then rotated by $180^{\circ}$ in $\mathrm{S}_{z z}, \mathrm{~S}_{\mathrm{yy}}$, and $\mathrm{S}_{\mathrm{xx}}$ axes of the PAS. Selected poses were chosen such that the distances from U4O(P)-C39(O3') and A22(O3')-G26 (P) were $<1.59 \AA$ and $<4.9 \AA \times$ by the number of bulge residues. This eliminated degeneracies for all molecules except $U_{7} T A R$ measured in NMR buffer and $3 \mathrm{mM} \mathrm{Mg}^{2+}$ (the degenerate solution can be found in Supplemental Fig. 6B). Interhelical Euler angles for the allowed orientations were then calculated using an inhouse C program based on Euler-RNA (Bailor et al. 2007). RDCs for TAR variants were normalized relative to wtTAR using a nor- malization factor that is based on the ratio of helix $2 \vartheta$ values. In all cases, RDCs measured in the A-form helices showed an excellent fit to the idealized A-form geometry (Supplemental Fig. 6A, D), as described previously for wtTAR (Dethoff et al. 2008) and $\mathrm{U}_{2}$ TAR (Merriman et al. 2016).

\section{Chemical shift titrations and determination of $\mathbf{M} \mathbf{g}_{1 / 2}$}

Aromatic SOFAST-HMQCs (Sathyamoorthy et al. 2014) were collected on a $600 \mathrm{MHz}$ Bruker NMR spectrometer equipped with an $\mathrm{HCN}$ cryogenic probe. $12{ }^{13} \mathrm{C} /{ }^{15} \mathrm{~N}$ labeled samples of wtTAR and each bulge mutant was diluted to $25 \mu \mathrm{M}$ RNA at $500 \mu \mathrm{L}$ in NMR buffer after sample preparation (see above). Each sample was then subjected to $18 \mathrm{~h}$ of dialysis against $500 \times$ the sample volume of NMR buffer containing $0,0.025,0.05,0.01,0.2,0.4,0.8,1.6$, $3.2,6.4,12.8,25.6 \mathrm{mM} \mathrm{Mg}^{2+}$ using a $1 \mathrm{kDa}$ molecular weight cut off Tube-O-DIALYZER Medi unit (G-Biosciences). Buffer was changed after $3 \mathrm{~h}, 12 \mathrm{~h}$, and an additional $3 \mathrm{~h}$ to ensure complete thermodynamic equilibration. Additional dialysis titration experiments on wtTAR were conducted using the same dialysis protocol and Tube-O-DIALYZER Medi units. In one case, EDTA was removed from the NMR buffer and all subsequent buffers containing $\mathrm{Mg}^{2+}$ (Supplemental Fig. 1E). In the other, the [wtTAR] was $0.3 \mathrm{mM}$ and additional titration points were added $(0.075,0.15$, $0.25,0.3,0.6,1.2,2.4$, and $32 \mathrm{mM} \mathrm{Mg}^{2+}$ ) (Supplemental Fig. 1F).

Chemical shift values were measured using SPARKY (Goddard and Kneller, SPARKY 3, University of California, San Francisco) after processing in NMRPipe (Delaglio et al. 1995). Chemical shifts were fit to an expression (Equation 1) describing one site binding using an in-house python script available online (https://github. com/DrCornFlakes/ChemicalShitTitrations).

$$
\delta_{\text {obs }}=\delta_{u}+\Delta \delta\left(\frac{\left[M g_{\text {free }}^{2+}\right]}{M g_{1 / 2}+\left[M g_{\text {free }}^{2+}\right]}\right)
$$

where $\delta_{\text {obs }}$ is the observed chemical shift, $\delta_{\mathrm{u}}$ is the fitted chemical shift of the unstacked state, $\Delta \delta$ is the difference between the chemical shift of the unstacked and the stacked state, and $\mathrm{Mg}_{1 / 2}$ is apparent equilibrium constant for $\mathrm{Mg}^{2+}$ binding. In the case of resonances that report on stacking, it is assumed to be the concentration of $\mathrm{Mg}^{2+}$ in which the RNA has a $50 \%$ population between stacked and unstacked states. The expression assumes that any chemical shift is only sensitive to one $\mathrm{Mg}^{2+}$-dependent transition. Note that carrying out the titrations using buffer exchange simplifies this expression since the concentration of free $\left[\mathrm{Mg}^{2+}\right]$ is known, one does not have to solve for total and free concentrations of $\left[\mathrm{Mg}^{2+}\right]$. Fits are shown in Supplemental Figure 3, with listed fitted parameters in Supplemental Table 2.

The uncertainty in the fitted parameters was estimated using Monte-Carlo simulations. Briefly, for a given TAR variant, all CSPs were fit to Equation 1. The differences between the measured CPSs and values back-calculated from a fit to Equation 1 were then fit to a Gaussian distribution to obtain a standard deviation $\sigma_{1}$. Simulations were then performed in which each CSP data point was perturbed by an amount determined by selecting values from the Gaussian distribution, and the noise corrupted data was then refit to Equation 1. Simulations were repeated 2000 times and the standard deviation in each fitted parameter was used to approximate the uncertainty in the fitted parameter (Supplemental Tables 1,5), which are shown in Supplemental Figure 3. 
The nonlinear CSP trajectory of A22-C8 in $\mathrm{U}_{2} T A R$ was fitted (Supplemental Fig. 4) to a more complex model (Equation 2) that assumes two independent binding sites (Arai et al. 2012),

$$
\begin{aligned}
& \delta_{\text {obs }}= \\
& \frac{\delta_{u} M g_{1 / 2(1)} M g_{1 / 2(2)}+\delta_{u-M g_{++}}\left(M g_{1 / 2(1)}+M g_{1 / 2(2)}\right)+\delta_{s}\left[M g_{\text {free }}^{2+}\right]^{2}}{M g_{1 / 2(1)} M g_{1 / 2(2)}+\left(M g_{1 / 2(1)}+M g_{1 / 2(2)}\right)+\left[M g_{\text {free }}^{2+}\right]^{2}},
\end{aligned}
$$

where $\delta_{\mathrm{u}}$ is the chemical shift of the unstacked state, $\delta_{x-M g}$ is the chemical shift of the unknown helical $\mathrm{Mg}^{2+}$-dependent event, $\delta_{\mathrm{s}}$ is the chemical shift of the stacked state, and $\mathrm{Mg}_{1 / 2(1)}$ and $\mathrm{Mg}_{1 / 2(2)}$ are the fitted equilibrium constants. Supplemental Table 2 lists fitted parameters with the standard error between measured and fitted data.

\section{PDB survey of RNA two-way junction structure}

All available nucleic acid X-ray structures in the PDB (Berman et al. 2000) released before August 16, 2017 were downloaded as biological assemblies. An in-house Python script based on previous work (Zhou et al. 2015) was adopted to search and extract coordinates of all two-way junctional motifs. DSSR (Lu et al. 2015) was used to parse sequence and structural information into a complete database using an in-house python code (https://github. com/alhashimilab/RNAJunction). Euler angles were computed using an in-house python script based on Euler RNA (https:// github.com/alhashimilab/ABG_calc) (Bailor et al. 2010, 2011a).

\section{Molecular dynamics simulations}

\section{$U_{2}$ TAR molecular dynamics simulation}

A 3.3 msec continuous MD simulation was run using AMBER 12 (Case et al. 2017) and the ff99bsc0 force field (Zgarbová et al. 2011). Starting coordinates were obtained from model 1 of the NMR solved structure of $U_{2}$ TAR (Brodsky and Williamson 1997) (PDBID: 1ANR) after removing the small molecule argininamide. A total of 33,000 conformers were utilized in the distance measurements (Supplemental Fig. 7).

\section{SUPPLEMENTAL MATERIAL}

Supplemental material is available for this article.

\section{COMPETING INTEREST STATEMENT}

H.M.A. is an advisor to and holds an ownership interest in Nymirum, an RNA-based drug discovery company.

\section{ACKNOWLEDGMENTS}

We would like to thank Antony M. Mustoe for helpful discussions, members of the Al-Hashimi laboratory for input and advice, and the Duke NMR Center for maintenance and assistance with the instruments. This work was supported by the US National Institutes of Health PO1 GM0066275.

Received March 2, 2018; accepted July 5, 2018.

\section{REFERENCES}

Aboul-ela F, Karn J, Varani G. 1996. Structure of HIV-1 TAR RNA in the absence of ligands reveals a novel conformation of the trinucleotide bulge. Nucleic Acids Res 24: 3974-3981.

Al-Hashimi HM, Gosser Y, Gorin A, Hu W, Majumdar A, Patel DJ. 2002. Concerted motions in HIV-1 TAR RNA may allow access to bound state conformations: RNA dynamics from NMR residual dipolar couplings. J Mol Biol 315: 95-102.

Al-Hashimi HM, Pitt SW, Majumdar A, Xu W, Patel DJ. 2003. Mg ${ }^{2+}$-induced variations in the conformation and dynamics of HIV-1 TAR RNA probed using NMR residual dipolar couplings. $J$ Mol Biol 329: 867-873.

Aragiannis P, Ujita Y, Aito H. 2016. RNA-based gene circuits for cell regulation. Proc Japan Acad Ser B 92: 412-422.

Arai M, Ferreon JC, Wright PE. 2012. Quantitative analysis of multisite protein-ligand interactions by NMR: binding of intrinsically disordered p53 transactivation subdomains with the TAZ2 domain of CBP. J Am Chem Soc 134: 3792-3803.

Bailor MH, Musselman C, Hansen AL, Gulati K, Patel DJ, AlHashimi HM. 2007. Characterizing the relative orientation and dynamics of RNA A-form helices using NMR residual dipolar couplings. Nat Protoc 2: 1536-1546.

Bailor MH, Sun X, Al-Hashimi HM. 2010. Topology links RNA secondary structure with global conformation, dynamics, and adaptation. Science 327: 202-206.

Bailor MH, Mustoe AM, Brooks CL, Al-Hashimi HM. 2011a. 3D maps of RNA interhelical junctions. Nat Protoc 6: 1536-1545.

Bailor MH, Mustoe AM, Brooks CL III, Al-Hashimi HM. 2011b. Topological constraints: using RNA secondary structure to model 3D conformation, folding pathways, and dynamic adaptation. Curr Opin Struct Biol 21: 296-305.

Bao L, Zhang X, Jin L, Tan Z-J. 2016. Flexibility of nucleic acids: from DNA to RNA. Chinese Phys B 25: 141515.

Bassi GS, Mollegaard NE, Murchie Al, von Kitzing E, Lilley DM. 1995. lonic interactions and the global conformations of the hammerhead ribozyme. Nat Struct Biol 2: 45-55.

Berkhout B. 1992. Structural features in TAR RNA of human and simian immunodeficiency viruses: a phylogentic analysis. Nucleic Acids Res 20: 27-31.

Berman HM, Westbrook J, Feng Z, Gilliland G, Bhat TN, Weissig H, Shindyalov IN, Bourne PE. 2000. The protein data bank. Nucleic Acids Res 28: 235-242.

Bhattacharyya A, Lilley DMJ. 1989. The contrasting structures of mismatched DNA sequences containing looped-out bases (bulges) and multiple mismatches (bubbles). Nucleic Acids Res 17: 6821-6840.

Bhattacharyya A, Murchie AlH, Lilley DMJ. 1990. RNA bulges and the helical periodicity of double-stranded RNA. Nature 343: 484-487.

Brodsky AS, Williamson JR. 1997. Solution structure of the HIV-2 TARargininamide complex. J Mol Biol 267: 624-639.

Calnan BJ, Biancalana S, Hudson D, Frankel AD. 1991. Analysis of arginine-rich peptides from the HIV Tat protein reveals unusual features of RNA-protein recognition. Genes Dev 5: 201-210.

Carter-O'Connell I, Booth D, Eason B, Grover N. 2008. Thermodynamic examination of trinucleotide bulged RNA in the context of HIV-1 TAR RNA. RNA 14: 2550-2556.

Case DA, Cerutti DS, Cheatham TE III, Darden TA, Duke RE, Giese TJ, Gohlke H, Goetz AW, Greene D, Homeyer N, et al. 2017. AMBER 2017, University of California, San Francisco.

Casiano-Negroni A, Sun X, Al-Hashimi HM. 2007. Probing $\mathrm{Na}^{+}$-induced changes in the HIV-1 TAR conformational dynamics using NMR residual dipolar couplings: new insights into the role of counterions and electrostatic interactions in adaptive recognition. Biochemistry 46: 6525-6535. 
Cech TR, Steitz JA. 2014. The noncoding RNA revolution-trashing old rules to forge new ones. Cell 157: 77-94.

Chen H, Meisburger SP, Pabit SA, Sutton JL, Webb WW, Pollack L, Chen H, Pollack L, Meisburger SP. 2012. lonic strength-dependent persistence lengths of single-stranded RNA and DNA. Proc Natl Acad Sci 109: 799-804.

Chu VB, Lipfert J, Bai Y, Pande VS, Doniach S, Herschlag D. 2009. Do conformational biases of simple helical junctions influence RNA folding stability and specificity? RNA 15: 2195-2205.

Cruz JA, Westhof E. 2009. The dynamic landscapes of RNA architecture. Cell 136: 604-609.

Davis B, Afshar M, Varani G, Murchie AlH, Karn J, Lentzen G, Drysdale MJ, Bower J, Potter AJ, Starkey ID, et al. 2004. Rational design of inhibitors of HIV-1 TAR RNA through the stabilisation of electrostatic "Hot Spots". J Mol Biol 336: 343-356.

Delaglio F, Grzesiek S, Vuister GW, Zhu G, Pfeifer J, Bax A. 1995. NMRPipe: a multidimensional spectral processing system based on UNIX pipes. J Biomol NMR 6: 277-293.

Dethoff EA, Hansen AL, Musselman C, Watt ED, Andricioaei I, AlHashimi HM. 2008. Characterizing complex dynamics in the transactivation response element apical loop and motional correlations with the bulge by NMR, molecular dynamics, and mutagenesis. Biophys J 95: 3906-3915.

Dethoff EA, Chugh J, Mustoe AM, Al-Hashimi HM. 2012. Functional complexity and regulation through RNA dynamics. Nature 482: 322-330.

Dickson A, Mustoe AM, Salmon L, Brooks CL III. 2014. Efficient in silico exploration of RNA interhelical conformations using Euler angles and WExplore. Nucleic Acids Res 42: 12126-12137.

Do TN, Ippoliti E, Carloni P, Varani G, Parrinello M. 2012. Counterion redistribution upon binding of a Tat-protein mimic to HIV-1 TAR RNA. J Chem Theory Comput 8: 688-694.

Duchardt-Ferner E, Weigand JE, Ohlenschläger O, Schmidtke SR, Suess B, Wöhnert J. 2010. Highly modular structure and ligand binding by conformational capture in a minimalistic riboswitch. Angew Chem Int Ed 49: 6216-6219.

Eddy SR. 2001. Non-coding RNA genes and the modern RNA world. Nat Rev Genet 2: 919-929.

Eichhorn CD, Al-Hashimi HM. 2014. Structural dynamics of a singlestranded RNA-helix junction using NMR. RNA 20: 782-791.

Eichhorn CD, Feng J, Suddala KC, Walter NG, Brooks CL, AlHashimi HM. 2012. Unraveling the structural complexity in a single-stranded RNA tail: implications for efficient ligand binding in the prequeuosine riboswitch. Nucleic Acids Res 40: 1345-1355.

Faber C, Sticht H, Schweimer K, Rosch P. 2000. Structural rearrangements of HIV-1 Tat-responsive RNA upon binding of neomycin B. J Biol Chem 275: 20660-20666.

Frank AT, Stelzer AC, Al-Hashimi HM, Andricioaei I. 2009. Constructing RNA dynamical ensembles by combining MD and motionally decoupled NMR RDCs: new insights into RNA dynamics and adaptive ligand recognition. Nucleic Acids Res 37: 3670-3679.

Fürtig B, Richter C, Wöhnert J, Schwalbe H. 2003. NMR spectroscopy of RNA. Chembiochem 4: 936-962.

Gesteland RF, Cech TR, Atkins JF. 2006. The RNA world, 3rd ed. Cold Spring Harbor Laboratory Press, Cold Spring Harbor, NY.

Getz MM, Andrews AJ, Fierke CA, Al-Hashimi HM. 2007. Structural plasticity and $\mathrm{Mg}^{2+}$ binding properties of RNase P P4 from combined analysis of NMR residual dipolar couplings and motionally decoupled spin relaxation. RNA 13: 251-66.

Gohlke C, Murchie AlH, Lilley DMJ, Clegg RM. 1994. Kinking of DNA and RNA helices by bulged nucleotides observed by fluorescence resonance energy transfer. Proc Natl Acad Sci 91: 11660-11664.

Hansen AL, Al-Hashimi HM. 2006. Insight into the CSA tensors of nucleobase carbons in RNA polynucleotides from solution mea- surements of residual CSA: towards new long-range orientational constraints. J Magn Reson 179: 299-307.

Hennig M, Williamson JR. 2000. Detection of $\mathrm{N}-\mathrm{H} \cdots \mathrm{N}$ hydrogen bonding in RNA via scalar couplings in the absence of observable imino proton resonances. Nucleic Acids Res 28: 1585-1593.

Hermann T. 2016. Small molecules targeting viral RNA. Wiley Interdiscip Rev RNA 7: 726-743.

Hermann T, Patel DJ. 2000. RNA bulges as architectural and recognition motifs. Structure 8: R46-R54.

Hermann T, Westhof E. 2000. Rational drug design and high-throughput techniques for RNA targets. Comb Chem High Throughput Screen 3: 219-234.

Herschlag D, Lipfert J, Sim AYL, Doniach S. 2010. Dissecting electrostatic screening, specific ion binding, and ligand binding in an energetic model for glycine riboswitch folding. RNA 16: 708-719.

Hsieh C-H, Griffith JD. 1989. Deletions of bases in one strand of duplex DNA, in contrast to single-base mismatches, produce highly kinked molecules: possible relevance to the folding of single stranded nucleic acids. Proc Natl Acad Sci 86: 4833-4837.

Ignacio Tinoco JR, Puglisi JD, Wyatt JR. 1989. RNA folding: pseudoknots, loops and bulges. Bioessays 11: 100-106.

Ippolito JA, Steitz TA. 1998. A 1.3-Å resolution crystal structure of the HIV-1 trans-activation response region RNA stem reveals a metal ion-dependent bulge conformation. Proc Natl Acad Sci 95: 9819-9824.

Jack A, Ladner JE, Klug A. 1976. Crystallographic refinement of yeast phenylalanine transfer RNA at $2.5 \AA$ resolution. J Mol Biol 108: 619-649.

Jalalirad M, Saadatmand J, Laughrea M. 2012. Dominant role of the $5^{\prime}$ TAR bulge in dimerization of HIV-1 genomic RNA, but no evidence of TAR-TAR kissing during in vivo virus assembly. Biochemistry 51: 3744-3758.

Jones KA, Peterlin BM. 1994. Control of RNA initiation and elongation at the HIV-1 promoter. Annu Rev Biochem 63: 717-743.

Kalnik MW, Norman DG, Li BF, Swann PF, Patel DJ. 1990. Conformational transitions in thymidine deoxytridecanucleotide duplexes. J Biol Chem 256: 636-647.

Kim SH, Suddath FL, Quigley GJ, Mcpherson A, Sussman JL, Wang AHJ, Seeman NC, Rich A. 1974. Three-dimensional tertiary structure of yeast phenylalanine transfer RNA. Science 185: 435-440.

Leulliot N, Varani G. 2001. Current topics in RNA-protein recognition: control of specificity and biological function through induced fit and conformational capture. Biochemistry 40: 7947-7956.

Lilley DMJ. 1995. Kinking of DNA and RNA by base bulges. Proc Natl Acad Sci 92: 7140-7142.

Losonczi JA, Andrec M, Fischer MWF, Prestegard JH. 1999. Order matrix analysis of residual dipolar couplings using singular value decomposition. J Magn Reson 138: 334-342.

Lu J, Kadakkuzha BM, Zhao L, Fan M, Qi X, Xia T. 2011. Dynamic ensemble view of the conformational landscape of HIV-1 TAR RNA and allosteric recognition. Biochemistry 50: 5042-5057.

Lu X-J, Bussemaker HJ, Olson WK. 2015. DSSR: an integrated software tool for dissecting the spatial structure of RNA. Nucleic Acids Res 43: e142.

Meissner A, Sorensen OW. 1999. The role of coherence transfer efficiency in design of TROSY-type multidimensional NMR experiments. J Magn Reson 139: 439-442.

Merriman DK, Xue Y, Yang S, Kimsey IJ, Shakya A, Clay MC, AlHashimi HMHM. 2016. Shortening the HIV-1 TAR RNA bulge by a single nucleotide preserves motional modes over a broad range of timescales. Biochemistry 55: 4445-4456.

Miao Z, Westhof E. 2017. RNA structure: advances and assessment of 3D structure prediction. Annu Rev Biophys 46: 483-503.

Murchie AlH, Davis B, Isel C, Afshar M, Drysdale MJ, Bower J, Potter AJ, Starkey ID, Swarbrick TM, Mirza S, et al. 2004. 
Structure-based drug design targeting an inactive RNA conformation: exploiting the flexibility of HIV-1 TAR RNA. J Mol Biol 336: 625-638.

Murphy FL, Wang Y-H, Griffith JD, Cech TR. 1994. Coaxially stacked RNA helices in the catalytic center of the tetrahymena ribozyme. Science 265: 1709-1712.

Musselman C, Pitt SW, Gulati K, Foster LL, Andricioaei I, AlHashimi HM. 2006. Impact of static and dynamic A-form heterogeneity on the determination of RNA global structural dynamics using NMR residual dipolar couplings. J Biomol NMR 36: 235-249.

Mustoe AM, Bailor MH, Teixeira RM, Brooks CL III, Al-Hashimi HM. 2012. New insights into the fundamental role of topological constraints as a determinant of two-way junction conformation. Nucleic Acids Res 40: 892-904.

Mustoe AM, Al-Hashimi HM, Brooks CL III. 2014a. Coarse grained models reveal essential contributions of topological constraints to the conformational free energy of RNA bulges. J Phys Chem B 118: 2615-2627.

Mustoe AM, Brooks CL, Al-Hashimi HM. 2014b. Hierarchy of RNA functional dynamics. Annu Rev Biochem 83: 441-466.

Noller HF. 2005. RNA structure: reading the ribosome. Science 309: 1508-1514.

Ohno H, Saito H. 2016. RNA and RNP as building blocks for nanotechnology and synthetic biology. Prog Mol Biol Transl Sci 139: 165-185.

Parella T. 2006. Bruker Biospin Pulse Program Catalogue: I. 1D \& 2D NMR Experiments. Topspin v20. Bruker BioSpin GmbH, Billerica, $M A$.

Pitt SW, Majumdar A, Serganov A, Patel DJ, Al-Hashimi HM. 2004. Argininamide binding arrests global motions in HIV-1 TAR RNA: comparison with $\mathrm{Mg}^{2+}$-induced conformational stabilization. $J$ Mol Biol 338: 7-16.

Pitt SW, Zhang Q, Patel DJ, Al-Hashimi HM. 2005. Evidence that electrostatic interactions dictate the ligand-induced arrest of RNA global flexibility. Angew Chem Int Ed 44: 3412-3415.

Prestegard JH, Al-Hashimi HM, Tolman JR. 2000. NMR structures of biomolecules using field oriented media and residual dipolar couplings. Q Rev Biophys 33: 371-424.

Puglisi JD, Tan R, Calnan BJ, Frankel AD, Williamson JR. 1992. Conformation of the TAR RNA-arginine complex by NMR spectroscopy. Science 257: 76-80.

Riordan FA, Bhattacharyya A, McAteer S, Lilley DMJ. 1992. Kinking of RNA helices by bulged bases, and the structure of the human immunodeficiency virus transactivator response element. $J \mathrm{Mol}$ Biol 226: 305-310.

Robertus JD, Ladner JE, Finch JT, Rhodes D, Brown RS, Clark BFC, Klug A. 1974. Structure of yeast phenylalanine tRNA at $3 \AA$ resolution. Nature 250: 546-551.

Roy S, Delling U, Chen C-H, Rosen CA, Sonenberg N. 1990. A bulge structure in HIV-I TAR RNA is required for Tat binding and Tat-mediated trans-activation. Genes Dev 4: 1365-1373.

Salmon L, Bascom GD, Andricioaei I, Al-Hashimi HM. 2013. A general method for constructing atomic-resolution RNA ensembles using NMR residual dipolar couplings: the basis for interhelical motions revealed. J Am Chem Soc 135: 5457-5466.

Sathyamoorthy B, Lee J, Kimsey IJ, Ganser LR, Al-Hashimi HM. 2014. Development and application of aromatic [13C, 1H] SOFASTHMQC NMR experiment for nucleic acids. J Biomol NMR 60: 77-83.

Shi YZ, Jin L, Wang FH, Zhu XL, Tan ZJ. 2015. Predicting 3D structure, flexibility, and stability of RNA hairpins in monovalent and divalent ion solutions. Biophys J 109: 2654-2665.

Shi X, Harbury PB, Herschlag D, Walker P. 2017. Determination of the conformational ensemble of the TAR RNA by X-ray scattering interferometry. Nucleic Acids Res 45: e64.
Somarowthu S. 2016. Progress and current challenges in modeling large RNAs. J Mol Biol 428: 736-747.

Stelzer AC, Kratz JD, Zhang Q, Al-Hashimi HM. 2010. RNA dynamics by design: biasing ensembles towards the ligand-bound state. Angew Chem Int Ed 49: 5731-5733.

Stelzer AC, Frank AT, Kratz JD, Swanson MD, Gonzalez-Hernandez MJ, Lee J, Andricioaei I, Markovitz DM, Al-Hashimi HM. 2011. Discovery of selective bioactive small molecules by targeting an RNA dynamic ensemble. Nat Chem Biol 7: 553-559.

Sumner-Smith M, Roy S, Barnett R, Reid LS, Kuperman R, Delling U, Sonenberg N. 1991. Critical chemical features in trans-acting-responsive RNA are required for interaction with human immunodeficiency virus type 1 Tat protein. J Virol 65: 5196-5202.

Sun X, Zhang Q, Al-Hashimi HM. 2007. Resolving fast and slow motions in the internal loop containing stem-loop 1 of HIV-1 that are modulated by $\mathrm{Mg}^{2+}$ binding: role in the kissing-duplex structural transition. Nucleic Acids Res 35: 1698-1713.

Tang RS, Draper DE. 1990. Bulge loops used to measure the helical twist. Biochemistry 29: 5232-5237.

Tjandra N, Bax A. 1997. Direct measurement of distances and angles in biomolecules by NMR in a dilute liquid crystalline medium. Science 278: 1111-1114.

Tolman JR, Flanagan MJ, Kennedy MA, Prestegard JH. 1997. NMR evidence for slow collective motions in cyanometmyoglobin. Nat Struct Mol Biol 4: 292-297.

Tolman JR, Al-Hashimi HM, Kay LE, Prestegard JH. 2001. Structural and dynamic analysis of residual dipolar coupling data for proteins. J Am Chem Soc 123: 1416-1424.

Turner DH. 1992. Bulges in nucleic acids. Curr Opin Struct Biol 2: 334-337.

Wahl MC, Will CL, Lü Hrmann R. 2009. The spliceosome: design principles of a dynamic RNP machine. Cell 136: 701-718.

Xiong Y, Sundaralingam M, Sudarsanakumar C, Deng J. 2001. Crystal structure of an RNA duplex r(gugcgcac)2 with uridine bulges. $J$ Mol Biol 313: 573-582.

Yang S, Salmon L, Al-Hashimi HM. 2014. Measuring similarity between dynamic ensembles of biomolecules. Nat Methods 11: 552-554.

Zacharias M, Hagerman PJ. 1995a. Bulge-induced bends in RNA: quantification by transient electric birefringence. $J$ Mol Biol 247: 486-500.

Zacharias M, Hagerman PJ. 1995b. The bend in RNA created by the trans-activation response element bulge of human immunodeficiency virus is straightened by arginine and Tat-derived peptide. Proc Natl Acad Sci 92: 6052-6056.

Zgarbová M, Otyepka M, Sponer J, MládekA, Banás P, Cheatham TE III, Jurečka P. 2011. Refinement of the Cornell et al. Nucleic acids force field based on reference quantum chemical calculations of glycosidic torsion profiles. J Chem Theory Comput 7: 2886-2902.

Zhang Q, Throolin R, Pitt SW, Serganov A, Al-Hashimi HM. 2003. Probing motions between equivalent RNA domains using magnetic field induced residual dipolar couplings: accounting for correlations between motions and alignment. J Am Chem Soc 125: 10530-10531.

Zhang Q, Sun X, Watt ED, Al-Hashimi HM. 2006. Resolving the motional modes that code for RNA adaptation. Science 311: 653-656.

Zhang Q, Stelzer AC, Fisher CK, Al-Hashimi HM. 2007. Visualizing spatially correlated dynamics that directs RNA conformational transitions. Nature 450: 1263-1267.

Zhao B, Zhang Q. 2015. Measuring residual dipolar couplings in excited conformational states of nucleic acids by CEST NMR spectroscopy. J Am Chem Soc 137: 13480-13483.

Zhou H, Hintze BJ, Kimsey IJ, Sathyamoorthy B, Yang S, Richardson JS, Al-Hashimi HM. 2015. New insights into Hoogsteen base pairs in DNA duplexes from a structure-based survey. Nucleic Acids Res 43: 3420-3433. 

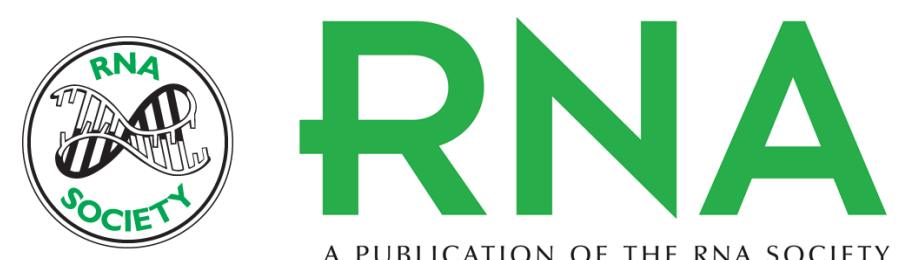

A PUBLICATION OF THE RNA SOCIETY

\section{Increasing the length of poly-pyrimidine bulges broadens RNA conformational ensembles with minimal impact on stacking energetics}

Dawn K. Merriman, Jiayi Yuan, Honglue Shi, et al.

RNA 2018 24: 1363-1376 originally published online July 16, 2018

Access the most recent version at doi:10.1261/rna.066258.118

\section{Supplemental http://rnajournal.cshlp.org/content/suppl/2018/07/16/rna.066258.118.DC1 Material}

References This article cites 100 articles, 22 of which can be accessed free at: http://rnajournal.cshlp.org/content/24/10/1363.full.html\#ref-list-1

Creative This article is distributed exclusively by the RNA Society for the first 12 months after the Commons License full-issue publication date (see http://rnajournal.cshlp.org/site/misc/terms.xhtml). After 12 months, it is available under a Creative Commons License (Attribution-NonCommercial 4.0 International), as described at http://creativecommons.org/licenses/by-nc/4.0/.
Email Alerting Receive free email alerts when new articles cite this article - sign up in the box at the Service top right corner of the article or click here.

\section{III!" P Providing Precise Solutions tor your research.}

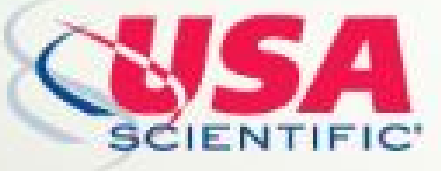

To subscribe to $R N A$ go to:

http://rnajournal.cshlp.org/subscriptions 